AL. 2.2003-46

c.2

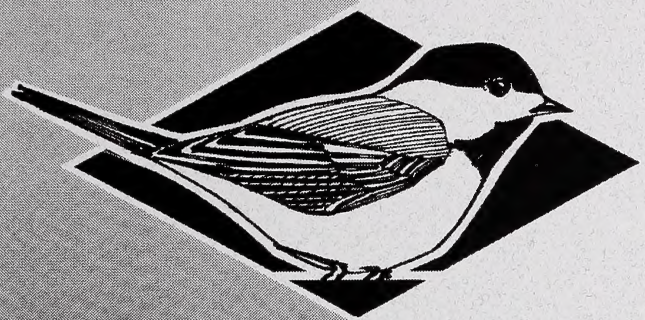

Fish \& Wilolite Division

RESOURGE STATUS AWD ASSESSMENT BRANCH

\title{
Alberta Inventory for the Northern Leopard Frog (2000/2001)
}

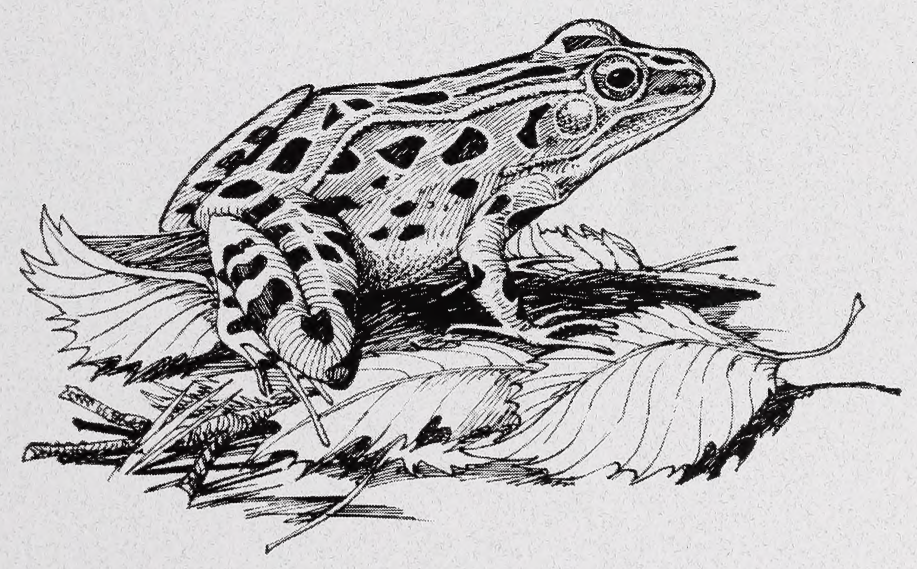


Digitized by the Internet Archive in 2016 


\title{
Alberta Inventory for the Northern Leopard Frog (2000/2001)
}

\author{
Kris Kendell
}

Alberta Species at Risk Report No. 44

April 2002

Project Partners:

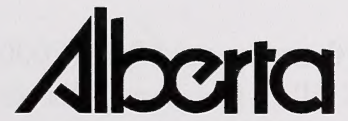

SUSTAINABLE RESOURCE DEVELOPMENT

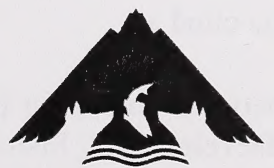

Alberta Conservation Association 
Publication No.: I/061

ISBN: 0-7785-2163-X (Printed Edition)

ISBN: 0-7785-2164-8 (On-line Edition)

ISSN: 1496-7219 (Printed Edition)

ISSN: 1496-7146 (On-line Edition)

Illustration: Brian Huffman

For copies of this report, contact:

Information Center - Publications

Alberta Environment/Alberta Sustainable Resource Development

Main Floor, Great West Life Building

9920108 Street

Edmonton, Alberta, Canada T5K 2M4

Telephone: (780) 422-2079

\section{OR}

Information Service

Alberta Environment/Alberta Sustainable Resource Development \#100, 311512 Street NE

Calgary, Alberta, Canada T2E 7J2

Telephone: (403) 297-3362

\section{OR}

Visit our web site at:

http://www3.gov.ab.ca/srd/fw/riskspecies/

This publication may be cited as:

Kendell, K. 2002. Alberta inventory for the northern leopard frog (2000/2001). Alberta Sustainable Resource Development, Fish and Wildlife Division, Alberta Species at Risk Report No. 44, Edmonton, AB. 29 pp. 


\section{DISCLAIMER}

The views and opinions expressed are those of the author and do not necessarily represent the policies or positions of the Department or the Alberta Government. 
Acknowledgements vi

Executive Summary vii

1.0 INTRODUCTION 1

2.0 STUDY AREA 4

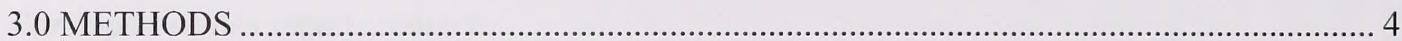

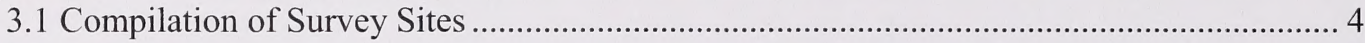

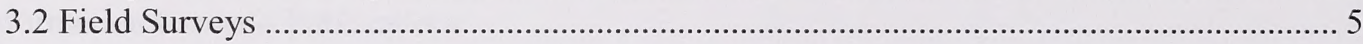

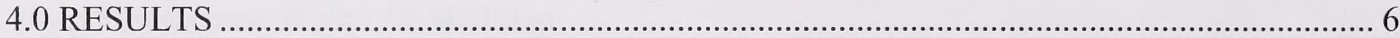

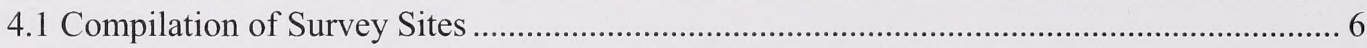

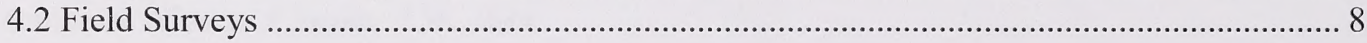

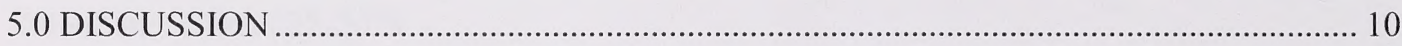

6.0 MANAGEMENT IMPLICATIONS AND FUTURE DIRECTIONS .................................. 12

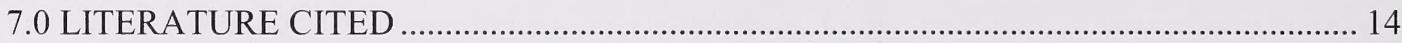

Appendix 1. Northern leopard frog observations during the 2000/2001 inventory................ 18

Appendix 2. Northern leopard frog sites surveyed with no leopard frogs observed during the 2000/2001 inventory.

Appendix 3. Northern leopard frog sites not investigated during the 2000-2001 inventory because access was denied, poor site description or coordinates, or other reason.

Appendix 4. List of all sites occupied by leopard frogs during the 2000-2001 inventory grouped by drainage; the number of sites associated with each drainage, tributary or waterbody are indicated in brackets.

Appendix 5. Nine major leopard frog populations identified during the 1990 inventory (Wershler 1991) and their current status with respect to the presence of frogs at one or more sites as of 2001

Appendix 6. Sites occupied by leopard frogs in 1990 (Wershler 1991) compared with results from the 2000-2001 at the same sites. 


\section{LIST OF FIGURES}

Figure 1. North American range of the northern leopard frog (adapted from Stebbins 1985)....... 1

Figure 2. Northern leopard frog (Rana pipiens). ………......................................................... 2

\section{LIST OF MAPS}

Map 1. Map depicting Fish and Wildlife Division regional boundaries in Alberta.

4

Map 2. Historic distribution of leopard frog sites in Alberta (pre-2000). Solid circles $(n=269)$ indicate sites surveyed in 2000 and 2001 and open circles $(n=28)$ indicate sites not surveyed in 2000 and 2001

Map 3. Sites where at least one leopard frog was observed (solid circles) and sites where no frogs were observed (open circles) during the 2000 and 2001 surveys. 


\section{ACKNOWLEDGEMENTS}

The author would first like to thank Alberta Sustainable Resource Development (SRD) - Fish and Wildlife Division and the Alberta Conservation Association (ACA). If not for their funding and 'in kind' support, this project would have not been possible.

I would also like to acknowledge the following individuals (alphabetically) for their contribution of time and energy to this project: Teresa Augustyn (SRD), Matt Besko (SRD), Dawn Birn (ACA), Ron Bjorge (SRD), Christine Boulton (University of Alberta), Steve Brechtel (SRD), Andrew Didiuk (Canadian Wildlife Service), Patsy Drummond (ACA), Candace Elchuk (University of Saskatoon), Lance Engley (ACA), Gary Erickson (SRD), Dale Eslinger (SRD), John Folinsbee (SRD), Christine Found (SRD), Ed Hofman (SRD), Henk Kiliaan, Greg McClelland (ACA), Corey Moes (SRD), Dave Moore (SRD), Elaine Nepstad (SRD), Dale Paton, Mark Piorecky (SRD), Dave Prescott (SRD), Richard Quinlan (SRD), Sheila Rangen (SRD), John Rintoul (Parks and Protected Areas Division - Community Development), Reg Russell (SRD), Roy Schmelzeisen (ACA), Georgina Shumaker (ACA), Tara Szkorupa (SRD), Lisa Takats (ACA), Bruce Treichel (SRD), Drajs Vujnovic (Parks and Protected Areas Division - Community Development), Michelle Wells (ACA), Mark Wendlandt (University of Calgary), Lisa Wilkinson (SRD), Johnathan Wright (Canadian Wildlife Service), Jan Young (ACA) and Pat Young (SRD).

A special thanks is owed to the Alberta Natural Heritage Information Centre (ANHIC) for initially organizing the leopard frog records stored in the Biodiversity Species Observation Database (BSOD) that were subsequently used for the 2000 and 2001 inventory.

Finally, a special thanks is owed to Donna Rystephanuk (ACA) for mapping support and Steve Brechtel (SRD), Sue Cotterill (SRD), Lance Engley (ACA), Dave Prescott (SRD), and Lisa Takats (ACA) for their editorial comments.

My sincere apologies to anyone I have neglected. 


\section{EXECUTIVE SUMMARY}

The northern leopard frog (Rana pipiens) was once a widespread species found throughout much of southern and central Alberta. In the late 1970s, the leopard frog exhibited a dramatic decline in distribution and numbers throughout much of its historic range in Alberta. Today, the leopard frog is designated as "Threatened" under Alberta's Wildlife Act. The Committee on the Status of Endangered Wildlife in Canada (COSEWIC) lists the prairie population of Rana pipiens as "Special Concern" (COSEWIC 2001).

Since 1990, no province-wide survey has been conducted to assess distribution and status of extant populations of the leopard frog in Alberta. A two-year inventory project was initiated in 2000 and completed in 2001 to collect information on the current status of the leopard frog in the province and to determine possible changes in population numbers and distribution. In total, 297 leopard frog sites were compiled for investigation. These sites were obtained from record information held in the Alberta Fish and Wildlife Division, Biodiversity Species Observation Database (BSOD).

To help increase the efficiency and maximize survey efforts for leopard frogs, a survey protocol was drafted in the spring of 2000 and subsequently revised in 2002. The protocol recommended the use of call surveys and an area search technique (visual encounter survey) as the primary survey method for leopard frogs. However, call surveys were employed on a very limited basis in the spring because of time constraints and were subsequently abandoned for more efficient visual encounter surveys later in the summer. Surveys were conducted in potentially suitable frog habitat to maximize the chance of observations and targeted in late summer to correspond with the emergence of young-of-the-year frogs. The late summer surveys also provided an added benefit of identifying waterbodies used for breeding and determining the successful development eggs and metamorphosis of tadpoles.

In total, 269 sites were investigated for the northern leopard frog in 2000 and 2001 and frogs were found at 54 of these sites. The majority of the leopard frog observations were associated with major river drainages including the lower Red Deer River, the Oldman River, the South Saskatchewan River, lower Bow River and the Milk River. Leopard frogs were also observed in the Cypress Hills region, Willow Creek drainage (west of Stavely) and in the extreme northeast region of Alberta.

Presence data at surveyed sites in 2000-2001 was compared to survey results from a provincial leopard frog inventory conducted by Sweet Grass Consultants Ltd. in 1990 (Wershler 1991). Results in 2000-2001 indicate that the northern leopard frog has experienced additional local extirpations over the last decade from four occupied sites that were surveyed in 1990. Findings from the 2000-2001 inventory also suggest that the species has not re-colonized formerly occupied parts of its range since its dramatic decline in the 1970s. In addition, many of the existing leopard frog sites remain fragmented and isolated. This, in-conjunction with the low recolonization potential of the leopard frog, may result in further local loss of populations if these sites experience disease, disturbance or catastrophic events such as winter mortality caused by anoxic conditions or loss of breeding habitat over consecutive years because of drought. 


\subsection{INTRODUCTION}

The northern leopard frog (Rana pipiens) is a member of the family Ranidae or 'true frogs'. Ranidae representatives can be found on all continents except Antarctica (Stebbins and Cohen 1995). Rana pipiens is broadly distributed across central North America (Figure 1). With the exception of local extirpations of populations (especially in the western portion of its range), the current and historical ranges are by and large similar (Wagner 1997).

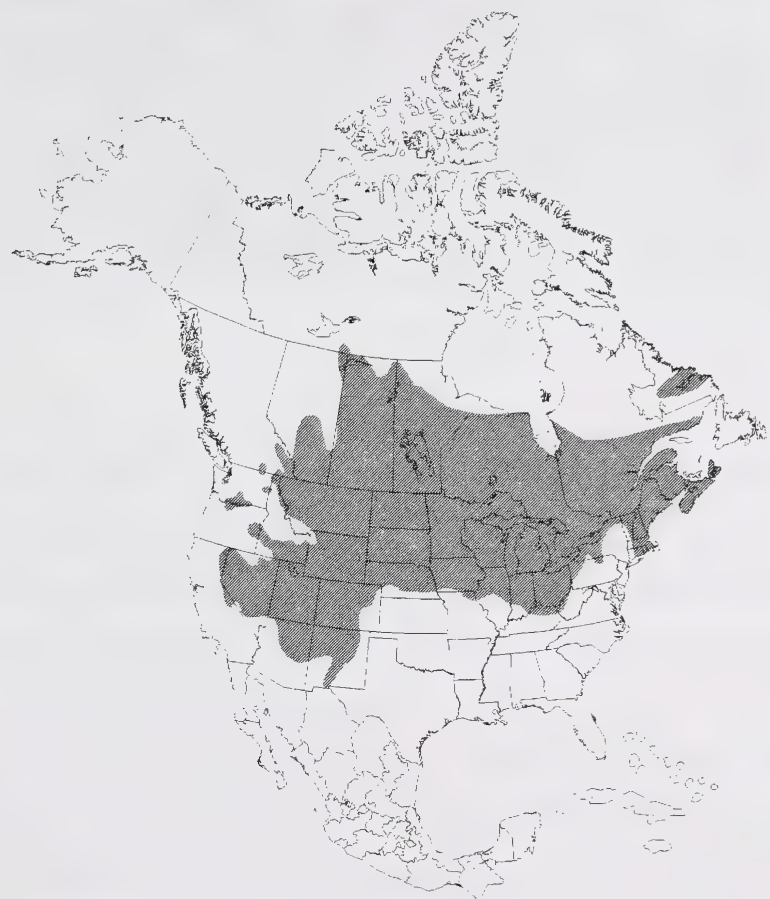

Figure 1. North American range of the northern leopard frog (adapted from Stebbins 1985).

Once considered to be a wide-ranging species with considerable variation (Moore 1944), more recently the leopard frog has been recognized to be a part of a complex of several species. This complex is based primarily on a wide difference in body size, coloration and pattern (Nace et al. 1996) as well as call structure (Pace 1974). Rana pipiens is the only member of the complex found in Canada (Seburn and Seburn 1998).

The northern leopard frog is a slim frog with smooth skin and long hind legs that are used for powerful leaps and swimming. Mature female frogs are somewhat larger than male frogs and may obtain a total body length (snout-to-vent) of about $10 \mathrm{~cm}$. Typically, background skin coloration ranges from various shades of green to brown; occasionally golden, blue or other colour morphs are described (Nace et al. 1996, Russell and Bauer 2000). The leopard frog can be easily distinguished from other frog and toad species in the province by the presence of a pair of continuous lightly coloured ridges extending behind the eyes to the lower back near the groin. 
They also possess circular dark spots with light borders, which are irregularly placed on the dorsal aspect of the frog (Russell and Bauer 2000) (Figure 2).

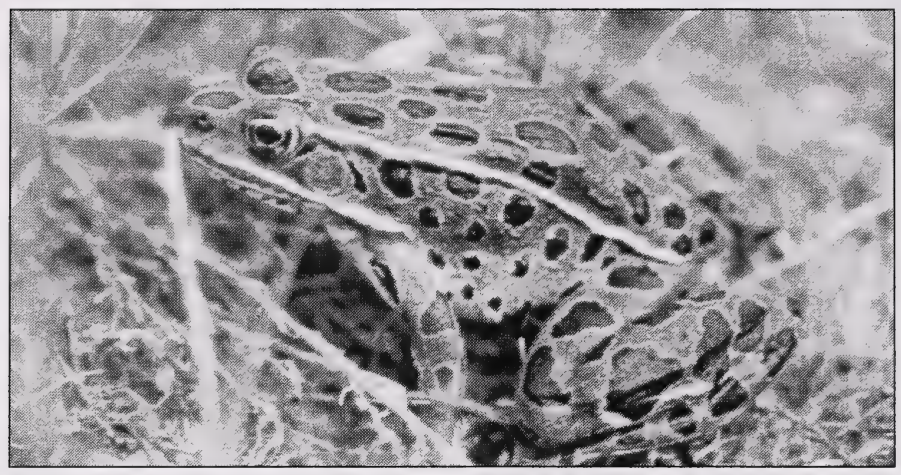

Figure 2. Northern leopard frog (Rana pipiens).

Rana pipiens can be found in a wide variety of terrestrial and aquatic habitats that, in combination, provide suitable breeding, summer and winter habitat. The leopard frog commonly breeds in marshes, sloughs, oxbows, beaver ponds, shallow bays and margins of lakes and quiet backwaters of streams and rivers (Merrell and Rodell 1968, Eddy 1976, Cottonwood Consultants 1986, Wershler 1991, Seburn and Seburn 1998). Generally, breeding habitat has some degree of permanence, abundant aquatic and emergent vegetation and areas of shallow water that receive direct sunlight for the deposition of egg masses (Wershler 1991, Gilbert et al. 1994). Later, the frogs typically spend the summer near water, which they can easily access to escape predators. However, they have a tendency to wander, and if sufficient moisture and cover vegetation are available, they may be found a considerable distance from waterbodies (Hine et al. 1981, Seburn et al. 1997). Leopard frogs hibernate underwater in aquatic environments to escape freezing temperatures (Emery et al. 1972, Cunjak 1986, McAdam and Nagel-Hisey 1998, Ultsch et al. 2000). To ensure winter survival, they require waterbodies that do not freeze to the bottom and possess adequate dissolved oxygen levels and water temperatures.

Once a common and widespread species throughout much of Canada, Rana pipiens has declined or vanished from much of the western and northern portion of its range (Wagner 1997, Seburn and Seburn 1998). The decline began in the 1960s in eastern North America and spread westward reaching Alberta in the late 1970s (Roberts 1981, Roberts 1994, Wagner 1997). Based on the Alberta Natural Region Classification System' (Achuff et al. 1988), the leopard frog once ranged from the Grassland Natural Region, north into the Parkland Natural Region and west into the Southern Foothill Subregion of Alberta. Today, it is confined primarily to the south and southeast portions of the province, primarily occupying the Mixedgrass and Dry Mixedgrass Subregions (including the Montane Subregion of the Cypress Hills). A remnant extent population occurs in the extreme northeast portion of the province, east of Wood Buffalo National Park, in the Kazan Upland Subregion.

${ }^{1}$ To view a current map depicting the Natural Regions and Subregions of Alberta visit the Alberta Natural Heritage Information Centre (ANHIC) web site: (http://www.cd.gov.ab.ca/preserving/parks/anhic/abnatreg.html). 
In Manitoba and Saskatchewan, the historic range of the leopard frog appears to be intact, although the number and size of populations have decreased (Seburn and Seburn 1998). In British Columbia, Rana pipiens is virtually extirpated, with only a single small population persisting within the Creston Valley (Seburn and Seburn 1998, D. Adama, pers. comm.). In Alberta, the decline resulted in a significant range contraction and reduction in population numbers, leaving the leopard frog absent from much of its northern and western range limit (Wagner 1997). Available information on extant leopard frog populations in Alberta suggests it is largely extirpated from the Central Parkland and Lower Foothills Subregions, and it is completely absent from the North Saskatchewan and upper Red Deer River drainage basins (Wagner 1997, Biodiversity Species Observation Database 2000). Consequently, in 1996 the northern leopard frog was designated as "Threatened" under Alberta's Wildlife Act.

Factors responsible for this dramatic decline in populations and numbers in western Canada (including Alberta) are unclear. Disease, drought and degradation and loss of habitat are commonly suggested as possible agents responsible for the decline. However, no single factor or combinations of casual factors have been demonstrated (Roberts 1981, 1994). Specific natural history requirements make the leopard frog particularly sensitive to human activities and natural events. For example, because the species hibernates underwater during the winter, it is susceptible to water management and use practices that could potentially affect water depth and flow rates during the winter. The degradation of wintering habitat could lead to high winter mortality if the water column completely freezes or conditions under the ice become anoxic. This, coupled with the perceived decline in numbers and populations, led to the prairie population being listed as "Special Concern" by the Committee on the Status of Endangered Wildlife in Canada (COSEWIC 2001).

A number major breeding sites of leopard frogs are well known in Alberta and have been documented in some detail over recent times (e.g., Wershler 1992, Yaremko 1994, Hofman 1995, Seburn et al. 1997). However, until this study, little attention had been given to a relatively large number of historic leopard frog sites in the province. As a result, virtually no information was available regarding the current status of these sites. The purpose of the northern leopard frog inventory was to clarify the status of the leopard frog in Alberta as of 2001. The main objectives of the inventory were to: (1) determine the occurrence of leopard frogs at historic and more current sites; (2) determine relative abundance of leopard frogs at sites where they exist; (3) determine breeding success of leopard frogs at sites where they exist; and (4) determine a trend in occupancy at sites, compared to survey results of Wershler (1991). 


\subsection{STUDY AREA}

The leopard frog inventory was conducted on a province-wide scale and encompassed all of Alberta. Surveys were conducted in all Alberta Fish and Wildlife Division regions (Map 1) where previous leopard frog records were found. The majority of the work was conducted in the Prairie, Bow and Parkland Regions, where the bulk of the records occurred. In contrast, relatively few records occurred in the Northwest Boreal, Northeast Boreal and Northern East Slopes Regions. As a result, work in these regions was minimal.

\section{Northeast \\ Boreal \\ Region}

Northwest Boreal

Region

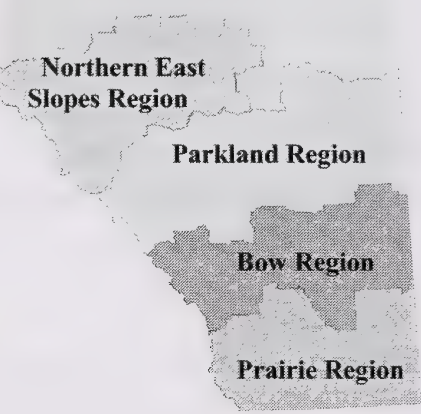

Map 1. Map depicting Fish and Wildlife Division regional boundaries in Alberta.

\subsection{METHODS}

\subsection{Compilation of Survey Sites}

Leopard frog sites to be investigated were obtained from the Biodiversity Species Observation Database (BSOD). Maintained by Alberta Fish and Wildlife Division, BSOD stores observational data primarily on species at risk or of undetermined status. Information held in this database is directly available to employees of Alberta Fish and Wildlife Division and the Alberta Conservation Association. The data is also available to the public by contacting one of the organizations mentioned above. All survey personnel had access to the database and could review the leopard frog records within it.

Each survey site was linked to at least one leopard frog record held in BSOD. However, sites with more than one associated BSOD record (occasionally dozens) were not uncommon. This phenomenon occurred when a number of BSOD records, generated by a variety of sources, over several dates, resulted in a number of records linked to the same site or general area. As a result, records associated with the same site were grouped together, resulting in a smaller number of 
records to be investigated, while leaving the total number of sites to be surveyed unchanged. Generally, records in BSOD that were separated by $2-3 \mathrm{~km}$ were considered to be separate sites (D. Vujnovic pers. comm.).

\section{$\underline{3.2 \text { Field Surveys }}$}

Fish and Wildlife Division Species at Risk (SAR) biologists conducted field surveys, in conjunction with summer staff, within their respective regional boundaries (see Map 1). Alberta Conservation Association biologists and temporary summer field staff, as well as a candidate M.Sc. student from the University of Calgary, also conducted surveys.

SAR biologists co-ordinating surveys were provided with a paper copy of all leopard frog sites within their Fish and Wildlife regional boundary. Information on specific observation details such as directions to the site, general description of the site, specific coordinates and all related BSOD records associated with the site were provided with the sites that had a high data reliability. Sites with lower data reliability were simply listed by their respective BSOD identification number. Information for all sites could be accessed from BSOD directly.

Regional SAR biologists conducting surveys or co-ordinating survey personnel were also provided with a Portable Document Format (PDF) map of all leopard frog sites within their Fish and Wildlife management region. All sites plotted on the map were labelled with a record number that could be used in BSOD to access corresponding information for the site. Each site on the map had a unique symbol and color, which provided information on the date of observation (i.e. last observed pre-1983, last observed post-1982 or no date given) and the precision of the record (i.e. within $250 \mathrm{~m}$, within $2.5 \mathrm{~km}$, or varying precision).

Survey personnel were provided with a survey protocol that communicated specific information on the preferred habitat, phenology and behaviour of the leopard frog. The protocol also provided instructions on survey methods. A time-constrained visual encounter survey was used as the primary sampling method for leopard frogs during the inventory. Under this method, optimal frog habitat was walked in a systematic and thorough fashion. At each site, the start and end search time was recorded and a minimum of 20 minutes was spent sampling. The total area (in square meters) searched at each site was also recorded as well as the actual or estimated numbers of leopard frogs observed in each search area. Additional information including weather conditions at the time of survey, habitat description, and management concerns as well as other herpetile species observed were also recorded on datasheets provided for the survey. The data sheet used during the inventory and a more detailed description of survey methods mentioned above are refined and summarized in Kendell (2002b).

The majority of the surveys were conducted in, or as close to, August as possible. In this way, surveys coincided with the metamorphosis and dispersal of young-of-the-year frogs from breeding ponds, potentially increasing the chance of an observation because of a higher density of frogs in a localized area. In addition, the observation of first year frogs verified successful breeding at those sites. It was determined that conducting a visual search under ideal weather conditions, in optimal habitat and during the appropriate time of day, was the most effective survey technique and maximized the chance of detecting frogs (Kendell 2002b). 


\subsection{RESULTS}

\subsection{Compilation of Survey Sites}

In total, 297 sites for leopard frogs were identified for survey in 2000 and 2001 (Map 2 and Appendices 1-3) based on record information held in BSOD. Twenty-eight sites were not surveyed because access was denied, poor co-ordinates were associated with the record, or other reason (Map 2 and Appendix 3).

Of the 297 sites surveyed, 136 were considered to have a high degree of data accuracy with regards to associated BSOD records. These sites had expert confirmation of the observation or audio detection of five or more adult frogs in the past. In addition, these sites included precise location information and data reliability. The remaining BSOD records $(n=161)$ frequently had insufficient information to determine the exact location of observation, low species identification reliability (i.e. questionable or speculative identification of the species observed) or were anecdotal observations without field confirmation. Nevertheless, attempts were made to investigate all sites.

Although the specific date of some records of the compiled data is unclear, the earliest confirmed record was 1903 and the most recent record was 1999. In general, more accurate information was associated with records that were more recent.

Data in the BSOD showed that historically the northern leopard frog occurred primarily throughout the Grassland and Parkland Natural Regions of the province. However, a limited number of records also occurred in the Boreal Forest, Foothills and Canadian Shield Natural Regions. Generally, the most westerly sites extended between Waterton National Park and north to the Rocky Mountain House area and included the Upper Foothills Natural Subregion. Several isolated records were also noted near the major centres of Hinton, Grand Prairie and High Level, as well as a number of areas north of Edmonton (Map 2). The most northerly records occurred in the extreme northeast corner of Alberta, north of Lake Claire and east of Wood Buffalo National Park, in the Kazan Upland Natural Subregion. Although many of the records appeared to be associated with major rivers, a number of records were dispersed between major drainages or associated with tributaries of larger rivers (Map 2). 


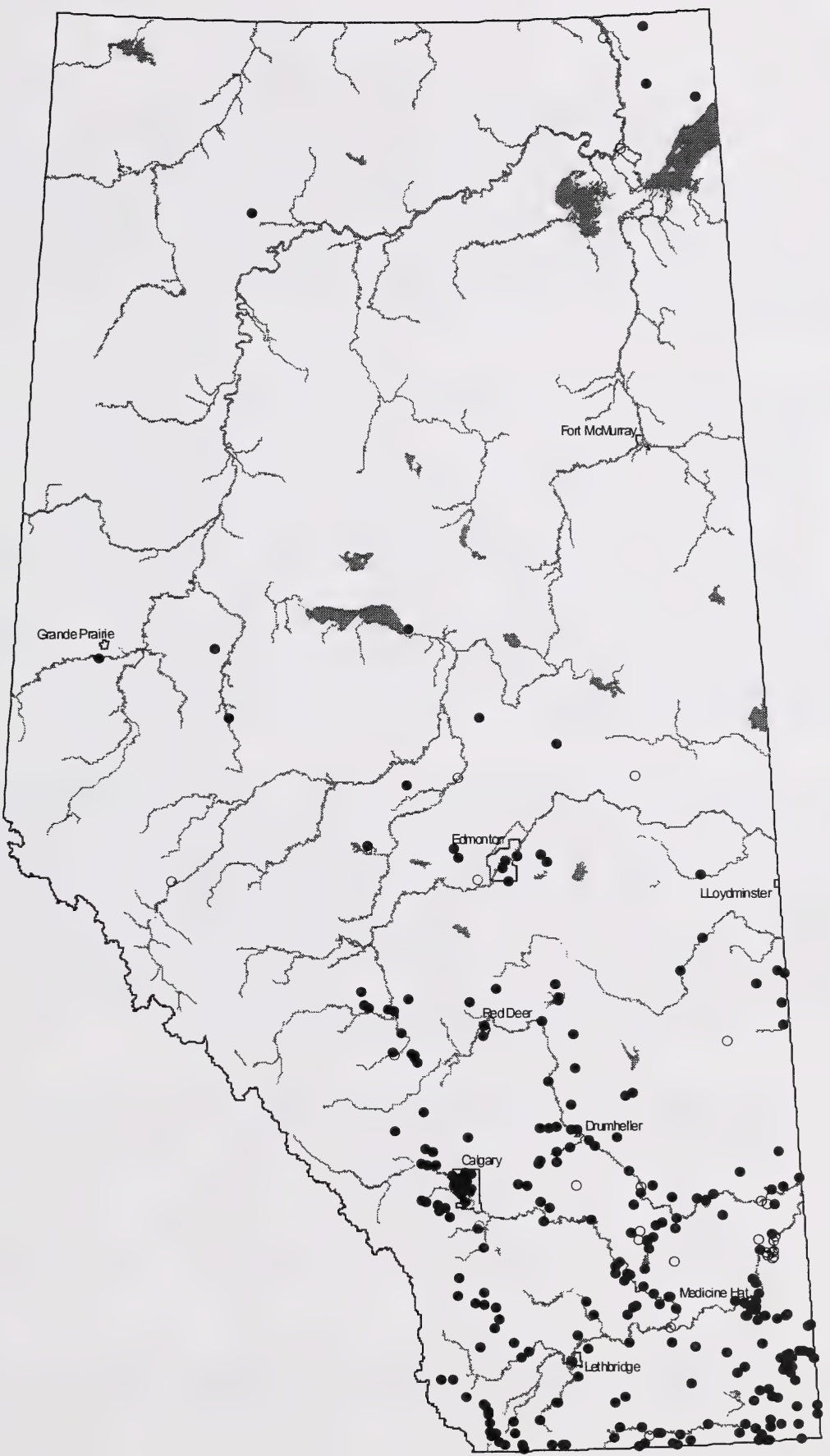

Map 2. Historic distribution of leopard frog sites in Alberta (pre-2000). Solid circles $(n=269)$ indicate sites surveyed in 2000 and 2001 and open circles $(n=28)$ indicate sites not surveyed in 2000 and 2001. 


\subsection{Field Surveys}

In total, 269 sites were investigated during the 2000 and 2001 field season. Of these sites, 220 were visited in 2000 and 49 were visited in 2001. Fifty-four sites were found to have leopard frogs (Map 3 and Appendices 1-2). Overall, field conditions during the 2000 and 2001 seasons were dry, and of the 269 sites investigated, 36 sites were found to be completely dry with no suitable frog habitat in the region and therefore were not visited. Seven of the sites investigated are now residential or commercial developments and occurred in or near major cities such as Calgary and Edmonton.

Of the 136 sites that had a high degree of data reliability, $94 \%(n=128)$ were surveyed, with leopard frogs occurring at $31 \%(n=40)$ of those sites. Of the 161 sites with lower data reliability, $88 \%(n=141)$ were surveyed, resulting in leopard frog observations at $10 \%(n=14)$ of those sites (Appendix 1). Of the 54 sites found to have leopard frogs, adults were observed at 41 sites and subadults were observed at 26 sites. Young-of-the-year leopard frogs were observed at 30 sites, representing confirmed breeding at those sites. Thirty-two sites $(60 \%)$ were found to have 10 or fewer frogs of one age class or another. Ten or more adult frogs were observed at three sites $(6 \%)$ and five sites $(9 \%)$ had 10 or more subadult frogs. The maximum number of adults observed at any site was 14 (Kennedy Coulee and Michelle Reservoir). The maximum number of subadult frogs recorded at one site was 31, near Graburn in the Cypress Hills. Hundreds of young-of-the-year frogs were observed at seven sites (Appendix 1).

Sites with leopard frogs occurred in 25 natural tributaries, which were associated with six major rivers in the province (Appendix 4). Sites were also associated with two man-made drainages (Lonesome Lake/Drainage K and Minipoka Drain) both of which flowed into the Bow River. Three sites were associated with tributaries or waterbodies in closed drainages (terminal basins) and not linked with a major river. These sites included Prince's Spring, McAlpine Creek (tributary of Many Island Lake) and Manyberries Creek, Ketchum Creek (tributaries of Pakowki Lake). Frogs were also observed at Stafford Lake (Red Deer River drainage), Leland Lake (Slave River drainage) and Whylie Lake (Slave River drainage).

Fifty-two sites occupied by frogs were located within the Grassland Natural Region and two sites were located in the Canadian Shield Natural Region. Leopard frog sites occurred in six Natural Subregions, including the Foothills Fescue $(n=3)$, Mixedgrass $(n=8)$, Northern Fescue $(n=2)$, Dry Mixedgrass $(n=35)$, Montane (Cypress Hills) $(n=4)$ and Kazan Upland $(n=2)$. With the exception of Medicine Hat, leopard frogs are extirpated from all major city's where they were previously documented to occur, including Edmonton, Red Deer, Calgary and Lethbridge (Map $3)$.

Hard copies of the data sheets and information collected during the 2000-2001 inventory are held at the Fish and Wildlife Office located in the O.S. Longman Building, Edmonton, Alberta. 


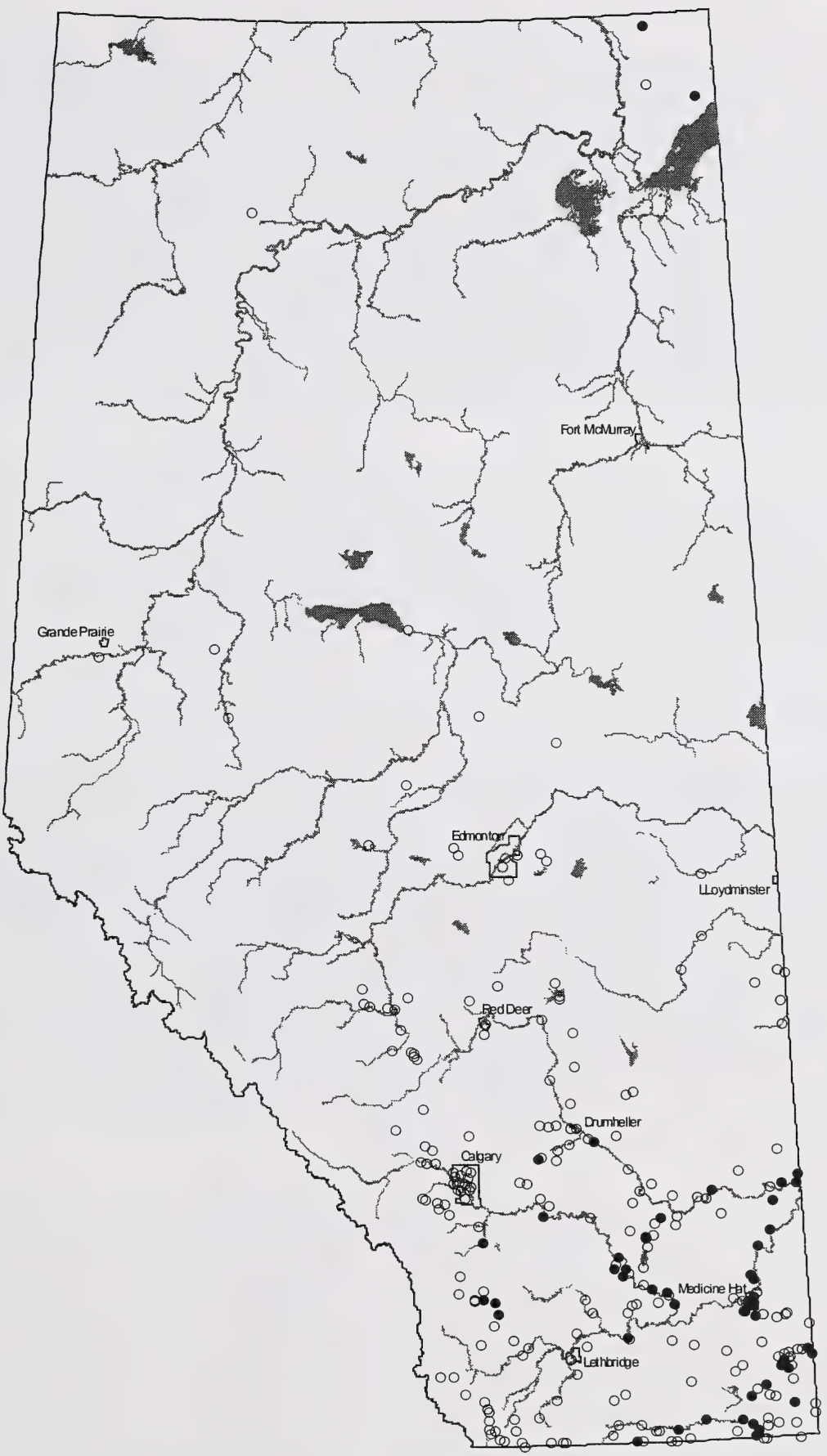

Map 3. Sites where at least one leopard frog was observed (solid circles) and sites where no frogs were observed (open circles) during the 2000 and 2001 surveys. 


\subsection{DISCUSSION}

Despite a wide geographical range across Canada, there have been few in-depth long-term studies of Canadian populations of the northern leopard frog (Seburn and Seburn 1998). In Alberta, a handful of inventory studies have been undertaken to better understand the distribution and status of the leopard frog. The most notable was a province-wide study in 1990 by Sweet Grass Consultants Ltd. (Wershler 1991). This study was followed by a monitoring project in 1991 by Sweet Grass Consultants Ltd., in which nine sites identified from the province-wide assessment the previous year were selected for a more intensive site assessment (Wershler 1992). A number of more intensive monitoring and census studies have been undertaken at Prince's Spring and in the Cypress Hills region of the province (e.g., Hofman 1991, 1992, 1995, Yaremko 1994, Seburn 1994, Seburn et al. 1997). However, these studies were not provincial in scope, and focussed on specific regions or known frog sites.

The 2000-2001 inventory is most similar to the province-wide assessment of the leopard frog status in Alberta, conducted in 1990 (Wershler 1991). Both studies involved field surveys at documented historic sites and more recent sites. In both studies, most sites were field-checked in August, however, sites were only visited once during the 2000-2001 inventory, whereas in 1990, several sites were visited multiple times. There is no information with respect to the amount of time spent searching or the total area searched at each site in Wershler's report. This, coupled with the fact that multiple visits were made to some sites, limits its comparability to the 20002001 results with respects to occupied leopard frogs sites.

Wershler (1991) identified ten major populations (Appendix 5) in 1990, and these were defined as "those that represent significant clusters of townships and included some productive sites from the 1970s to the present or include sites where significant numbers of either adults or young-ofthe-year were found". What constitutes a "significant number", in Wershler's report, is not defined. During 2000-2001, frogs were observed at eight of the ten major populations identified by Wershler (1991) (Appendix 5). The exceptions were the Lost River-Canal Creek site (which was dry in 2000) and the Jenner Springs site (Appendices 5 and 6). With the exception of the Finnegan and Blood Indian Creek sites, young-of-the-year frogs were recorded within all major populations (identified by Wershler) where frogs were observed in 2000-2001. However, it should be noted that the Blood Indian Creek site was visited in June and therefore before the metamorphosis of any potential tadpoles. Similarly, the Finnegan site was visited on 1 August and potentially before metamorphosis of tadpoles.

Of the ten major populations documented in the 1990 report, four were considered to be significant sites in 2000-2001 (Appendix 5). Sites that were defined as significant possessed a relatively larger number of frogs (more then ten adult and subadult frogs combined) compared to other sites. These included the Cypress Hills (Sexton Creek), lower Milk River, Prince's Spring and Red Deer River/Finnegan sites. Three new significant sites were identified in 2000-2001 and included sites in the Willow Creek drainage near Stavely, sites along the South Saskatchewan in CFB Suffield, and sites near Bow City (Bow River) (Appendix 1).

Wershler (1991) observed frogs at 13 sites during field surveys and 11 sites that were identified through a poster campaign by Alberta Fish and Wildlife and World Wildlife Fund Canada (Prairie for Tomorrow) (Appendix 6). All 24 sites were considered reliable. In 2000-2001, 
leopard frogs were observed at 16 (67\%) of the 24 sites that were described by Wershler (1991). Of the sites where leopard frogs were not observed in 2000-2001, four were located south of Lethbridge, and south and west of Calgary. They included Beaver Creek/Porcupine Hills, Beaupre Creek, Horse Creek (west of Cochrane) and an oxbow along the St. Mary River. The apparent absence of frogs from these areas in 2000-2001 may demonstrate further erosion of the leopard frog sites from the western portion of its range between 1990 and 2001. However, it should be noted that the failure to detect leopard frogs at these, and other sites, does not necessarily indicate the absence of frogs at those sites. For example, frogs could have been overlooked or not active, therefore not observed. The Slack Sough site, located south of Red Deer, was also recorded by the poster campaign and yielded no observations in 2000-2001. The final two records associated with the poster campaign were located in the lower reaches of the Little Bow River, near its confluence with the Oldman River. No leopard frogs were observed at either site in 2000 and 2001. However, a population was recorded in the upper reaches of the Little Bow River, south of High River in 2000.

An accurate assessment of population size and frog numbers at the sites surveyed in 2000-2001 is not possible. This is largely because each site was only visited once. Environmental conditions such as weather and ambient temperatures at the time of survey could have been less than optimal during some surveys, reducing frog activity and consequently reducing the chance of visual encounter.

Many leopard frog records held in BSOD were associated with areas of the province easily accessed by people. Many of the sites were located near rural and urban centres, or other areas frequented by people. Because of this, the range interpreted from data collected during the inventory may be biased and the occurrence of leopard frogs elsewhere in the province may be underestimated. A number of areas of the province were not surveyed but could potentially contain suitable leopard frog habitat and support a population. Similarly, additional subpopulations within the known distribution could be possible. For example, young and adult leopard frogs are capable of long distance movements overtime and have been known to travel up to $2 \mathrm{~km}$ in a season, between habitats, and several kilometres over consecutive years (see Dole 1971, Rittschof 1975, Merrell 1977, Hine et al. 1981, Seburn et al. 1997). These findings provide compelling evidence that additional frog sites could occur in suitable habitat within the dispersal distance of the 54 occupied sites identified in 2000-2001.

Results of the 2000-2001 inventory reflect the population distribution of the leopard frog described by Wershler (1991), Wagner (1997) and Seburn and Seburn (1998). Inventory results demonstrated no range recovery of the leopard frog since its dramatic decline during the late 1970s. In addition, of the 24 sites leopard frogs were observed at in 1990, only $16(67 \%)$ were found to have frogs in 2000-2001. While the large population crash noted in the late 1970s is over, results from the 2000-2001 inventory suggest that leopard frog population numbers in Alberta are continuing to decline and frog sites continue to be isolated and fragmented from one another. 


\subsection{MANAGEMENT IMPLICATIONS AND FUTURE DIRECTIONS}

\section{Survey protocol:}

Call surveys for leopard frogs may be an inefficient method for detecting leopard frogs at sites because of their eruptive breeding behaviour, relatively quiet calls and sensitivity to environmental conditions that determine calling activity.

In contrast, late summer surveys (August), coinciding with metamorphosis of young-of-the-year, may maximize the chance of encountering frogs because of a higher density of animals (dispersing metamorphs) in a localized area. Late summer surveys also have the added benefit of assessing the reproductive success of a given site. For example, the presence of calling male frogs will not guarantee successful breeding with respect to the deposition and development of egg masses and complete metamorphosis of tadpoles and successful dispersal of young frogs.

Late summer and early fall may also be a potentially useful survey time, as adults and other age classes began to congregate along water bodies near potential hibernation sites. Late fall surveys are key in identifying important over-wintering sites. The revised northern leopard frog sampling protocol (Kendell 2002b) should be followed for future leopard frog inventories and for the general survey of leopard frogs in Alberta.

\section{Update of current status report:}

The leopard frog status report (Wagner 1997) should be updated to reflect recent information obtained during the 2000-2001 inventory and put forward for consideration by the Alberta Endangered Species Conservation Committee (ESCC) and re-evaluation of its legislative status.

A province wide census should be undertaken every five years to re-evaluate and determine the most current population status of the leopard frog at historic sites and more recent sites. Monitoring on a more frequent basis may be required to more accurately evaluate population demographics and habitat use at occupied leopard frog sites.

\section{Protection of Habitats:}

Over the last decade a wealth of information relating to the natural history, behaviour and habitat requirements of the northern leopard frog has been acquired through a number of studies and projects. To ensure extant populations of leopard frogs remain viable over the long-term, a new program should be created that focuses on the protection and enhancement of habitat at occupied sites. The primary objective of this program would focus on the protection and enhancement of critical habitats that are required by leopard frogs for breeding, summering and over-wintering. Of utmost importance will be maintaining a positive relationship between landowners and those agencies implementing a habitat program. Education and co-operation will be instrumental for such a program to be a success.

\section{Reintroduction Projects:}

The northern leopard frog exhibits many of the requirements proposed in conservation literature for successful translocations (Fisher 1999). Conservation-oriented translocations are proven and effective tools for the conservation of 'endangered' amphibian species and frequently result in the successful re-establishment of stable breeding populations (Conant 1988, Denton et al. 1997, Fisher 1999, Sarrazin 2000). 
In Alberta, remaining leopard frog populations are fragmented and isolated, making them vulnerable to disturbance, disease and natural disasters, which could potentially lead to further local extirpations. With minimal prospect of natural recolonization of its former distribution, the re-establishment of leopard frogs at historic sites is therefore dependent on transplanting individuals from existing major breeding populations in southern Alberta (Cottonwood Consultants 1986, Roberts 1987, Wershler 1991). The reintroduction of the leopard frog into its historic range would reduce its restricted breeding distribution and sensitivity to environmental changes and stresses that affect localized populations.

In 1998, the Alberta Fish and Wildlife Division began to explore the feasibility of reintroducing leopard frogs into formerly occupied habitats in the upper Red Deer River and North Saskatchewan River drainage basins in Alberta (Fisher 1999). A pilot reintroduction project was initiated in 1999 at the Raven Brood Trout Station near Caroline, Alberta (Wendlandt and Takats 1999). The project involved the captive rearing of leopard frogs from egg stage of development to metamorphosed frog, in two man-made outdoor ponds.

The primary objective of the project is to re-establish leopard frogs in the headwaters of the upper Red Deer River and North Saskatchewan River drainages, consequently allowing natural downstream dispersal along these watersheds. Over a three year period more than 4500 young of the year leopard frogs have been released into historic habitat in the upper headwaters of the Red Deer River near Caroline, Alberta (Kendell 2001). In 2001, 750 young frogs were released at a new pilot release site in the upper headwaters of the North Saskatchewan River near Rocky Mountain House, Alberta (Kendell 2002a).

The observation of at least 10 individual leopard frogs and documentation of calling activity in 2001 at the Raven River reintroduction site provides compelling evidence for the initial success of the project (see Kendell 2002a). Long-term monitoring at release sites is critical to understanding dispersal rates, habitat use and general assessment of the productivity of established populations.

Results from the 2000-2001 inventory can be used to help identify new potential draw sites for egg masses to be used for captive rearing at the Raven Brood Trout Station and released at designated release sites. In addition, unoccupied sites identified during the inventory, in areas targeted for possible leopard frog reintroductions, could be considered as possible release sites. These sites would need to be carefully assessed in order to confirm that they are unoccupied by leopard frogs. Consideration should only be given to sites with long-term protection and with suitable breeding, summering and over-wintering habitat. 


\subsection{LITERATURE CITED}

Achuff, P.L., J. Godfrey and C. Wallis. 1988. A systems planning natural history framework and evaluation system for Alberta Recreation and Parks. Kanata Heritage Research report to Alberta Recreation and Parks, Edmonton. 3 vols.

Alberta Natural Heritage Information Centre (ANHIC). 2002. Natural regions and subregions of Alberta. URL: http://www.cd.gov.ab.ca/preserving/parks/anhic/abnatreg.html. [Last updated 20 December 1999].

Biodiversity Species Observation Database (BSOD). 2000. Sustainable Resource Development, Edmonton, Alberta.

Conant, S. 1988. Saving endangered species by translocation. BioScience Vol. 38, No. 4. Pp. 254-257.

COSEWIC, 2001. Canadian Species at Risk, May 2001. Committee on the Status of Endangered Wildlife in Canada. 31 pp.

Cottonwood Consultants. 1986. An overview of reptiles and amphibians in Alberta's grassland and parkland natural regions. Unpublished report funded by the World Wildlife Fund Canada (Wild West Program), Toronto, ON. 63+ pp.

Cunjak, R. A. 1986. Winter habitat of northern leopard frogs, Rana pipiens, in a southern Ontario stream. Canadian Journal of Zoology 64: 255-257.

Denton, J. S., S. P. Hitchings, T. J. C. Beebee and A. Gent. 1997. A recovery program for the natterjack toad (Bufo calamita) in Britian. Conservation Biology 11: No. 6: 1329-1338.

Dole, J. W. 1971. Dispersal of recently metamorphosed leopard frogs, Rana pipiens. Copeia 1971: 221-228.

Eddy, S. B. 1976. Population ecology of the leopard frog, Rana pipiens pipiens Schreber, at Delta Marsh, Manitoba. Unpublished Thesis, University of Manitoba.

Emery, A. R., A. H. Berst, and K. Kodaira. 1972. Under-ice observations of wintering sites of leopard frogs. Copeia 1: 123-126.

Fisher, C. 1999. Feasibility of northern leopard frog translocations in Alberta: a review of physiological, ecological, methodological requirements for successful repatriations and results from field investigations. Alberta Environment, Fisheries and Wildlife Management Division, Edmonton, AB. 35 pp.

Gibert, M., R. Leclair Jr., and R. Fortin. 1994. Reproduction of the northern leopard frog (Rana pipiens) in floodplain habitat in the Richelieu River, P. Quebec, Canada. Journal of Herpetology 28: 465-470. 
Hine, R. L., B. L. Les, and Hellmich, B. F. 1981. Leopard frog populations and mortality in Wisconsin, 1974-76. Technical Bulletin No. 122, Department of Natural Resources, Madison, WI. $39 \mathrm{pp}$.

Hofman, D. E. 1991. 1990 central region leopard frog inventory. Unpublished report, Alberta Fish and Wildlife Division, Red Deer, AB. 8 pp.

Hofman, D. E. 1992. 1992 Leopard frog monitoring project, Prince's Spring, Alberta. Unpublished report, Alberta Fish and Wildlife Division, Red Deer, AB. 12 pp.

Hofman, D. E. 1995. 1995 Northern leopard frog census, Prince's Spring, Alberta. Unpublished report, Alberta Natural Resources Service, Red Deer, AB. 6 pp.

Kendell, K. 2001. Northern leopard frog reintroduction: Raven river-year 2 (2000). Alberta Sustainable Resource Development, Fish and Wildlife Service, Alberta Species at Risk Report No. 13, Edmonton, AB. 43 pp.

Kendell, K. 2002a. Northern leopard frog reintroduction: year 3 (2001). Alberta Sustainable Resource Development, Fish and Wildlife Division, Alberta Species at Risk Report No. 42. $45 \mathrm{pp}$.

Kendell, K. 2002b. Survey protocol for the northern leopard frog. Alberta Sustainable Resource Development, Fish and Wildlife Division, Alberta Species at Risk Report No. 44, Edmonton, Alberta. $30 \mathrm{pp}$.

McAdam S. M., and M. Nagel-Hisey. 1998. Winter northern leopard frogs at Cypress Hills Inter-Provincial Park. Blue Jay 56: 166-168.

Merrell, D. J., and C. F. Rodell. 1968. Seasonal selection in the leopard frog, Rana pipiens. Evolution 22: 284-288.

Merrell, D. J. 1977. Life history of the leopard frog, Rana pipiens, in Minnesota. University of Minnesota Bell Museum of Natural history. Occupational Paper No. 15. 23 pp.

Moore, J. A. 1944. Geographic variation in Rana pipiens Schreber of eastern North America. Bulletin of the American Museum of Natural History 82: 345-370.

Nace, G. W., D. D. Culley, M. B. Emmons, E. L. Gibbs, V. H. Hutchison, and R. G. Mckinnel. 1996. Amphibians: guidelines for the breeding, care and management of laboratory animals. A report of the Subcommittee on Amphibian Standards, Committee on Standards, Institute of Laboratory Animals Resources and National Research Council National Academy of Sciences, Washington, D.C. 154 pp.

Pace, A. E. 1974. Systematic and biological studies of the leopard frog (Rana pipiens complex) of the United States. University of Michigan, Miscellaneous Publications in Zoology 148: 1-140. 
Rittschof, D. 1975. Some aspects of the natural history and ecology of the leopard frog, Rana pipiens. University of Michigan, Ann Arbor. Ph. D. Thesis. 212 pp.

Roberts, W. E. 1981. What happened to the leopard frog? Alberta Naturalist. 11: 1-4.

Roberts, W. E. 1987. The northern leopard frog endangered in Alberta. Pp. 137-138 in Endangered species in the prairie provinces (G. L. Holroyd, W. B. Mcgillivray, P. H. R. Stepney, D. M. Ealey, G. C. Trottier and K. E. Ederhart, eds.). Provincial Museum of Alberta Natural History Occupational Paper No. 9, Edmonton, AB. 367 pp.

Roberts, W. E. 1994. Amphibian decline? Maybe, maybe not. Environment. Network. News. Jan/Feb 11-13.

Russell, A. P., and A. M. Bauer. 2000. The amphibians and reptiles of Alberta. A field guide and primer of boreal herpetology. $2^{\text {nd }}$ ed. University of Alberta Press, Calgary, AB. 279 pp.

Sarrazin, F., and S. Legendre. 2000. Demographic approach to releasing adults versus young in reintroductions. Conservation Biology Vol. 14, No. 2. Pp. 488-500.

Seburn, C. N. L. 1994. Leopard frog project - progress report 1993. Unpublished report for Alberta Forestry, Lands and Wildlife, Edmonton, AB. 15 pp.

Seburn, C. N. L., and D. C. Seburn, and C. A. Paszkowski. 1997. Northern leopard frog (Rana pipiens) dispersal in relation to habitat. In Amphibians in Decline: Canadian Studies of a Global Problem, D. M. Green (Ed.). Herpetological Conservation. Society of the Study of Amphibian and Reptiles, St. Louis. 1:64-72.

Seburn, N. L., and D. C. Seburn. 1998. Status Report on the northern leopard frog, Rana pipiens, in Canada (western population). Prepared for the Committee on the Status of Endangered Wildlife in Canada, Ottawa, ON. 43 pp.

Stebbins, R. C. 1985. A field guide to western reptiles and amphibians, $2^{\text {nd }}$ edition. Houghton Mifflin, Boston, MA. $336 \mathrm{pp}$.

Stebbins, R. C., and N. W. Cohen. 1995. A natural history of amphibians. Princeton University Press, Princeton, NJ. 316 pp.

Ultsch, G. R., T. E. Graham, and C. E. Crocker. 2000. An aggregation of over-wintering leopard frogs, Rana pipiens, and common map turtles, Graptemys geographica, in northern Vermont. Canadian Field Naturalist 114(2): 314-315.

Wagner, G. 1997. Status of the Northern Leopard Frog (Rana pipiens) in Alberta. Alberta Environmental Protection, Wildlife Management Division, Wildlife Status Report No. 9, Edmonton, AB. $46 \mathrm{pp}$. 
Wendlandt, M., and Takats, L. 1999. Northern leopard frog reintroduction: Raven River - pilot year (1999). Alberta Environment, Fisheries and Wildlife Management Division, Edmonton, AB. 22 pp.

Wershler, C. R. 1991. Status of the northern leopard frog in Alberta - 1990. Unpublished report by Sweetgrass Consultants Ltd. for the World Wildlife Fund (Prairie for Tomorrow) and Alberta Forestry, Lands and Wildlife, Edmonton, AB. 81 pp.

Wershler, C. R. 1992. Northern Leopard Frog Monitoring - 1991. Unpublished report by Sweetgrass Consultants Ltd. for the World Wildlife Fund Canada (Prairie for Tomorrow) and Alberta Forestry, Lands and Wildlife, Fish and Wildlife Division, Edmonton, AB. 50 pp.

Yaremko, L. 1994. Northern leopard frog project - field report 1994. Unpublished report for Fish and Wildlife Service, Edmonton, AB. 85 pp. 
Appendix 1. Northern leopard frog observations during the 2000-2001 inventory.

\begin{tabular}{|c|c|c|c|c|c|c|c|}
\hline Record* & Date & Site Description & Latitude & Longitude & Adult & Sub-adult & YOY \\
\hline 31 & 26-Aug-00 & Red Creek, west of Coutts & 49.0 & -112.1 & 1 & & \\
\hline 38 & 2000 & Milk River Natural Area & 49.0 & -110.7 & 2 & & \\
\hline 107 & 28-Jul-00 & $\begin{array}{l}\text { Kennedy Creek, southeast of } \\
\text { Onefore }\end{array}$ & 49.0 & -110.7 & 14 & 7 & 350 \\
\hline 36 (2 sites) & 27-Aug-00 & $\begin{array}{l}\text { Police Creek; Writing on Stone } \\
\text { Provincial Park }\end{array}$ & 49.1 & -111.6 & & & 6 \\
\hline 32 & 4-May-00 & Breed Creek, north of Aden & 49.1 & -111.3 & 2 & 1 & \\
\hline 47 & 17-Aug-00 & $\begin{array}{l}\text { Milk River, south of Pakowki } \\
\text { Lake }\end{array}$ & 49.1 & -110.9 & 2 & 1 & 1 \\
\hline 39 & 18-Aug-00 & Milk River Natural Area & 49.1 & -110.7 & 1 & & 1 \\
\hline 8 & 5-Aug-00 & $\begin{array}{l}\text { Bare Creek, east of } \\
\text { Manyberries }\end{array}$ & 49.2 & -110.3 & 1 & 1 & \\
\hline 53 & 7-Aug-00 & $\begin{array}{l}\text { Ketchum Creek, east of } \\
\text { Pakowki Lake } \\
\end{array}$ & 49.3 & -110.8 & & & 1 \\
\hline 39042 & 7-Aug-00 & $\begin{array}{l}\text { Mannyberries area / tributary } \\
\text { of Manyberries Creek }\end{array}$ & 49.4 & -110.6 & 8 & & \\
\hline $8233 / 54255$ & $28-$ Aug-00 & $\begin{array}{l}\text { Michelle Reservoir, northeast } \\
\text { of Manyberries }\end{array}$ & 49.5 & -110.4 & 14 & 4 & 6 \\
\hline 8234 & 1-Aug-00 & $\begin{array}{l}\text { Lodge Creek, east of } \\
\text { Manyberries }\end{array}$ & 49.5 & -110.4 & 2 & & 153 \\
\hline 8214 & 28 -Aug-00 & $\begin{array}{l}\text { Thelma Creek, south of } \\
\text { Elkwater }\end{array}$ & 49.5 & -110.3 & & & 4 \\
\hline 8026 & 1-Aug-00 & Lodge Creek, Eagle Butte area & 49.6 & -110.4 & & & 30 \\
\hline 56 ( 8 sites) & 28-Jul-00 & $\begin{array}{l}\text { Sexton Creek and ponds; } \\
\text { Cypress Hills area }\end{array}$ & 49.6 & -110.3 & 32 & 4 & 785 \\
\hline 51281 & 27-Jul-01 & \begin{tabular}{|l} 
Graburn, Cypress Hills \\
Provincial Park
\end{tabular} & 49.6 & -110.0 & & 31 & \\
\hline 57 & 9-May-00 & $\begin{array}{l}\text { RANA Site, Cypress Hills } \\
\text { Provincial Park }\end{array}$ & 49.7 & -110.1 & 5 & 14 & \\
\hline 51320 & 7-Aug-00 & Oldman River, near Taber & 49.8 & -112.2 & 1 & & \\
\hline 14 & 24-Jul-00 & $\begin{array}{l}\text { Bullshead Creek, near } \\
\text { Dunmore }\end{array}$ & 49.9 & -110.8 & & & 44 \\
\hline 16 & 24-Jul-00 & $\begin{array}{l}\text { Seven Persons Creek, near } \\
\text { Medicine Hat }\end{array}$ & 49.9 & -110.8 & 1 & & 6 \\
\hline 119 & 28-Jul-00 & $\begin{array}{l}\text { Bullshead Reservoir, south of } \\
\text { Medicine Hat }\end{array}$ & 49.9 & -110.6 & 2 & 2 & 11 \\
\hline 11 & 21-Jul-01 & $\begin{array}{l}\text { McAlpine Creek, south of } \\
\text { Walsh }\end{array}$ & 49.9 & -110.0 & 3 & & \\
\hline 67 (2 sites) & 21-Aug-00 & $\begin{array}{l}\text { Willow Creek, west of } \\
\text { Claresholm }\end{array}$ & 50.0 & -113.7 & 6 & 5 & \\
\hline 63 & 24-Jul-00 & $\begin{array}{l}\text { Kin Coulee / Connaught Golf } \\
\text { Course, Medicine Hat }\end{array}$ & 50.0 & -110.7 & 1 & & 144 \\
\hline 5137 & 31-Aug-00 & $\begin{array}{l}\text { South Saskatchewan River, } \\
\text { Medicine Hat }\end{array}$ & 50.0 & -110.7 & & 1 & 5 \\
\hline 8027 & 31-Aug-00 & $\begin{array}{l}\text { South Saskatchewan River, } \\
\text { Medicine Hat }\end{array}$ & 50.0 & -110.7 & 2 & 6 & 1 \\
\hline 64 & 17-Jul-00 & Strathcona Park, Medicine Hat & 50.0 & -110.6 & 3 & & 199 \\
\hline
\end{tabular}

* Records 1 to 136 represent ANHIC records; other numbers indicate BSOD records; records in bold represent sites with 10 or more adult and subadult frogs combined.

YOY = Young-of-the-year. 
Appendix 1. continued

\begin{tabular}{|c|c|c|c|c|c|c|c|}
\hline Record* & Date & Site Description & Latitude & Longitude & Adult & Sub-adult & YOY \\
\hline 71 & 20-Aug-00 & Willow Creek, west of Stavely & 50.1 & -113.9 & 2 & 12 & \\
\hline 69 (3 sites) & 20-Aug-00 & Pine Coulee, west of Stavely & 50.1 & -113.7 & 5 & 36 & \\
\hline 131 & 24-Aug-00 & $\begin{array}{l}\text { Twelve Mile Coulee, near } \\
\text { Rolling Hills }\end{array}$ & 50.1 & -111.7 & & 3 & 4 \\
\hline 66 & 23-Aug-00 & Bow River, southeast of Hays & 50.1 & -111.6 & 3 & 3 & 3 \\
\hline 31624 & 31-Aug-00 & $\begin{array}{l}\text { South Saskatchewan River, } \\
\text { near Medicine Hat }\end{array}$ & 50.1 & -110.6 & & 3 & 1 \\
\hline 32403 & 24-Aug-00 & $\begin{array}{l}\text { Bow River, southwest of } \\
\text { Rolling Hills } \\
\end{array}$ & 50.2 & -111.8 & & 7 & 25 \\
\hline 73 & 14-Sep-00 & $\begin{array}{l}\text { South Saskatchewan River, } \\
\text { CFB Suffield }\end{array}$ & 50.2 & -110.7 & 3 & 11 & 5 \\
\hline 72 & 30 -Aug-00 & $\begin{array}{l}\text { Old Channel Lake, CFB } \\
\text { Suffield }\end{array}$ & 50.2 & -110.6 & & 5 & 13 \\
\hline 109 & 5-Aug-00 & $\begin{array}{l}\text { Lonesome Lake, south of Bow } \\
\text { City }\end{array}$ & 50.3 & -112.3 & 4 & 1 & 2 \\
\hline 75 & 5-Aug-00 & Circle E Ranch, near Bow City & 50.3 & -112.2 & 1 & & 6 \\
\hline 76 & 6-Aug-00 & Minipoka Drain, near Scandia & 50.3 & -112.2 & 1 & & \\
\hline 79 (3 sites) & 5-Aug-00 & Bow City area & 50.4 & -112.2 & 3 & 9 & 100 's \\
\hline 114 & $30-$ Sep-00 & Sherwood Forest, CFB Suffield & 50.5 & -110.6 & 1 & & \\
\hline 80 & 21-Jul-00 & $\begin{array}{l}\text { Little Bow River, south of } \\
\text { High River town site }\end{array}$ & 50.6 & -113.9 & 3 & & 8 \\
\hline 39181 & 18-Sep-01 & Stafford Lake, north of Brooks & 50.6 & -111.9 & 4 & & \\
\hline 113 & 5-Aug-00 & Whitco Springs, CFB Suffield & 50.6 & -110.4 & & 1 & \\
\hline 32397 & 29-Aug-01 & Princess, north of & 50.7 & -111.7 & 1 & & \\
\hline 82 & 4-Aug-00 & Bow River, near of Arrowwood & 50.8 & -113.1 & 2 & & 100 's \\
\hline 83 & $10-$ Aug-00 & $\begin{array}{l}\text { Princes Spring, north of CFB } \\
\text { Suffield }\end{array}$ & 50.8 & -110.3 & 7 & 3 & 5 \\
\hline 86 & 7-Jun-00 & $\begin{array}{l}\text { Blood Indian Creek, north of } \\
\text { Jenner }\end{array}$ & 50.9 & -111.1 & 4 & & \\
\hline 85 & 10 -Aug-00 & $\begin{array}{l}\text { Kennedy Coulee, east of } \\
\text { Empress }\end{array}$ & 50.9 & -110.2 & 2 & & \\
\hline 87 & 11-Aug-00 & Empress Creek, near Empress & 51.0 & -110.0 & 1 & & 3 \\
\hline 78 & 01-Aug-01 & Finnigan / Spring Creek & 51.1 & -112.1 & 6 & 6 & \\
\hline 93 & 28-Jun-00 & $\begin{array}{l}\text { Serviceberry Creek, near } \\
\text { Rockyford }\end{array}$ & 51.2 & -113.2 & & 1 & \\
\hline 118 & 20-Jun-00 & $\begin{array}{l}\text { Red Deer River, near Atlas } \\
\text { Coal Mine }\end{array}$ & 51.3 & -112.5 & 2 & & \\
\hline 2 & 19-Aug-00 & $\begin{array}{l}\text { Wylie Lake, east of Wood } \\
\text { Buffalo National Park }\end{array}$ & 59.3 & -110.3 & 1 & & \\
\hline 5479 & 20 -Aug-00 & Leland Lake, east of Fitzgerald & 59.9 & -111.0 & 1 & & \\
\hline
\end{tabular}

* Records 1 to 136 represent ANHIC records; other numbers indicate BSOD records; records in bold represent sites with 10 or more adult or subadult frogs combined.

YOY = Young-of-the-year.

Hard copies of the data sheets and information collected during the 2000 and 2001 inventory are held at the O.S. Longman Building, Edmonton, Alberta. 
Appendix 2. Northern leopard frog sites surveyed with no leopard frogs observed during the 2000-2001 inventory.

\begin{tabular}{|c|c|c|c|c|}
\hline Record* & Date & Site Description & Latitude & Longitude \\
\hline 6 & 9-Aug-00 & Belly River, west of Mountain View & 49.0 & -113.7 \\
\hline 19651 & 9-Aug-00 & Boundary Creek & 49.0 & -113.5 \\
\hline 51310 & 22-Jul-00 & Outpost Lake; Police Outpost Provincial Park & 49.0 & -113.5 \\
\hline 8042 & 23-Jul-00 & Rolph Creek, near Taylorville & 49.0 & -113.1 \\
\hline 8038 & 23-Jul-00 & Lynn Sommerfeldt land & 49.0 & -113.0 \\
\hline 51312 & 23-Jul-00 & $\begin{array}{l}\text { Milk River, near Writing On Stone Provincial } \\
\text { Park }\end{array}$ & 49.0 & -113.0 \\
\hline 41 & 26-Aug-00 & Red Creek, west of Coutts & 49.0 & -112.0 \\
\hline 40 & 26-Aug-00 & Police Creek; Writing On Stone Provincial Park & 49.0 & -111.7 \\
\hline 8170 & 30-Aug-01 & Milk River, 16 miles east and 8 miles south & 49.0 & -111.7 \\
\hline 51292 & 26-Aug-00 & St. Kilda area & 49.0 & -111.5 \\
\hline 1 & 26-Aug-01 & Milk River, west of Wild Horse & 49.0 & -110.6 \\
\hline 27 & 26-Aug-01 & Milk River, west of Wild Horse & 49.0 & -110.6 \\
\hline $8112 / 8121 / 51322$ & 29-Aug-00 & Wild Horse Area & 49.0 & -110.2 \\
\hline 51296 & 8-Aug-00 & Cottonwood Creek, south of Twin Butte & 49.1 & -113.9 \\
\hline 24 & 8-Aug-00 & Maskinonge Lake, near HWY 6 & 49.1 & -113.8 \\
\hline 35 & 9-Aug-00 & Crooked Creek, south of Twin Butte & 49.1 & -113.8 \\
\hline 5 & 9-Aug-00 & Sofa Mountain Beaver Ponds & 49.1 & -113.7 \\
\hline 3 & 9-Aug-00 & Romeril Dam, near Mountain View & 49.1 & -113.6 \\
\hline 8211 & 24-Jul-00 & Milk River Tributary, northeast of Del Bonita & 49.1 & -112.4 \\
\hline 26 & 24-Jul-00 & Milk River town site (lagoon) & 49.1 & -112.1 \\
\hline 28 & 26-Aug-00 & Milk River, southwest of Milk River town site & 49.1 & -111.9 \\
\hline 42 & 26-Aug-00 & Milk River, southwest of Milk River town site & 49.1 & -111.9 \\
\hline 29 & 15 -Aug-00 & Milk River, at Pinhorn Grazing Reserve & 49.1 & -110.9 \\
\hline 8201 & 29-Aug-00 & Lost River & 49.1 & -110.6 \\
\hline 43 & 19-Aug-00 & Lost River, west of Onefour & 49.1 & -110.5 \\
\hline 46 & 2000 & Onefour, area near & 49.1 & -110.5 \\
\hline 44 & 2000 & Sage Creek, east of Onefour & 49.1 & -110.3 \\
\hline 31610 & 2000 & $\begin{array}{l}\text { Dungaryan Creek, north of Waterton Lakes } \\
\text { National Park }\end{array}$ & 49.2 & -113.9 \\
\hline 51311 & 9-Aug-00 & Mami Creek, near Hillspring & 49.2 & -113.6 \\
\hline 4 & 22-Jul-00 & St. Mary River, near Spring Coulee & 49.2 & -113.3 \\
\hline 48 & 24-Aug-00 & Milk River Ridge, northeast of Del Bonita & 49.2 & -112.3 \\
\hline 45 & 19-Aug-00 & Canal Creek, northwest of Onefour & 49.2 & -110.6 \\
\hline 39037 & 29-Aug-00 & $\begin{array}{l}\text { Alberta/Saskatchewan boarder, south of Cypress } \\
\text { Hills Provincial Park }\end{array}$ & 49.2 & -110.1 \\
\hline 22 & 5 -Aug-00 & Yarrow Creek, west of Twin Butte & 49.3 & -113.9 \\
\hline 23 & 5-Aug-00 & Drywood Creek, north of Twin Butte & 49.3 & -113.9 \\
\hline 50 & $25-J u l-00$ & Middle Coulee, near McNab & 49.3 & -112.4 \\
\hline 48288 & 2000 & Mannyberries Creek, south east of Manyberries & 49.3 & -110.5 \\
\hline 54256 & 2000 & Sage Creek, near Onefour & 49.3 & -110.5 \\
\hline
\end{tabular}

* Records 1 to 136 represent ANHIC records; other numbers indicate BSOD records. 
Appendix 2. continued

\begin{tabular}{|c|c|c|c|c|}
\hline Record* & Date & Site Description & Latitude & Longitude \\
\hline 49 & 19-Aug-00 & $\begin{array}{l}\text { Middle Creek Reservoir - Lodge Creek, south of } \\
\text { Cypress Hills Provincial Park }\end{array}$ & 49.3 & -110.0 \\
\hline 127 & 4-Aug-00 & Beauvais Lake; Beauvais Lake Provincial Park & 49.4 & -114.1 \\
\hline 34 & 5-Aug-00 & Indian Farm Creek, near Pincher Creek town site & 49.4 & -113.9 \\
\hline 8319 & 5-Aug-00 & Foothills Creek, east of Pincher Creek town site & 49.4 & -113.9 \\
\hline 51 & 21-Jul-00 & Pinepound Creek, near Spring Coulee & 49.4 & -113.1 \\
\hline 54 & 21-Jul-00 & St. Mary River, Blood Indian Reserve & 49.4 & -113.1 \\
\hline $8203 / 51318$ & 24-Jul-00 & Tyrrell Lake (east side) & 49.4 & -112.2 \\
\hline 55 & 13 -Aug-00 & Manyberries Creek, near Manyberries & 49.4 & -110.7 \\
\hline 9 & $5-$ Aug-00 & Lodge Creek, south of Cypress Hills & 49.4 & -110.3 \\
\hline 32380 & 25 -Aug-00 & Foremost & 49.5 & -111.5 \\
\hline 32391 & 29-Aug-01 & Peigan Creek, south of & 49.5 & -110.9 \\
\hline 51317 & 4-Aug-00 & Frank Slide area & 49.6 & -114.4 \\
\hline 8035 & 4-Aug-00 & Burmis Bridge Marsh & 49.6 & -114.3 \\
\hline 8220 & 21-Jul-00 & Pothole Creek & 49.6 & -112.8 \\
\hline 15 & 2000 & Peigan Creek, south of Medicine Hat & 49.6 & -110.8 \\
\hline $51294 / 31626$ & 28-Aug-00 & Eagle Butte area & 49.6 & -110.4 \\
\hline 123 & 25 -Aug-00 & Spring Creek, Cypress Hills Provincial Park & 49.6 & -110.3 \\
\hline $8190 / 8200$ & 28 -Aug-00 & Thelma Creek & 49.6 & -110.3 \\
\hline 31629 & 29-Aug-01 & Elkwater, south of & 49.6 & -110.3 \\
\hline 51289 & 29-Jul-01 & Elkwater, south of - Cypress Hills Provincial Park & 49.6 & -110.3 \\
\hline 8315 & $10-$ Aug-00 & Oldman River Campground & 49.7 & -113.5 \\
\hline $8013 / 8033$ & 20-Jul-00 & Lethbridge, in or near & 49.7 & -112.9 \\
\hline 9522 & $25-$ Aug-00 & Bow Island, south of & 49.7 & -111.4 \\
\hline 8181 & 25 -Aug-00 & Seven Person's Creek (Red Rock Coulee) & 49.7 & -111.0 \\
\hline 13 & 10 -Aug-00 & Seven Persons, east of Bow Island & 49.7 & -110.6 \\
\hline 10 & 2000 & Elkwater Lake, Cypress Hills Provincial Park & 49.7 & -110.3 \\
\hline 8167 & 2000 & SW corner of Cypress Hill Provincial Park & 49.7 & -110.3 \\
\hline 31628 & 29-Aug-01 & Spruce Coulee (Cypress Hills Provincial Park) & 49.7 & -110.2 \\
\hline 31625 & 29-Aug-01 & $\begin{array}{l}\text { Graburn Monument / Gap, Cypress Hills } \\
\text { Provincial Park }\end{array}$ & 49.7 & -110.1 \\
\hline 59 & 3-Aug-00 & Beaver Creek, north of Pincher Creek town site & 49.8 & -113.9 \\
\hline 7479 & 3-Aug-00 & Moyninhan Ranch, west of Claresholm & 49.8 & -113.9 \\
\hline $32382-83$ & 10-Aug-00 & Willow Creek, west of Stavely & 49.8 & -113.5 \\
\hline 8036 & 10-Aug-00 & Willow Creek, Oldmam River confluence & 49.8 & -113.4 \\
\hline 58 & 21-Aug-00 & Oldman River, near Diamond City & 49.8 & -112.7 \\
\hline 7 & 7-Aug-00 & Oldman River, near Taber Municipal Park & 49.8 & -112.2 \\
\hline 37 & 25 -Aug- 00 & Yellow Lake, southwest of Bow Island & 49.8 & -111.7 \\
\hline $51319 / 8052$ & 22-Aug-00 & Picture Butte reservoir & 49.9 & -112.8 \\
\hline 51291 & $30-$ Aug- 00 & Cavan Lake Area & 49.9 & -110.4 \\
\hline 12 & 29-Aug-00 & Dunmore - Elkwater Lake turnoff & 49.9 & -110.3 \\
\hline 60 & 2000 & Mackay Creek, south of Walsh & 49.9 & -110.0 \\
\hline
\end{tabular}

* Records 1 to 136 represent ANHIC records; other numbers indicate BSOD records. 
Appendix 2. continued

\begin{tabular}{|c|c|c|c|c|}
\hline Record* & Date & Site Description & Latitude & Longitude \\
\hline 62 & 20 -Aug-00 & Trout Creek, west of Claresholm & 50.0 & -113.8 \\
\hline 65 & 7-Aug-00 & Little Bow, south of Travers Reservoir & 50.0 & -112.6 \\
\hline 51321 & 22-Aug-00 & Vauxhall reservoir & 50.0 & -112.2 \\
\hline 8225 & 6-Aug-01 & Irvine, west of & 50.0 & -110.6 \\
\hline 8327 & 2000 & Rose Creek, west of Irvine & 50.0 & -110.3 \\
\hline 31620 & 19-Aug-00 & Unnamed creek, at HWY 527 & 50.1 & -114.0 \\
\hline 31621 & 19-Aug-00 & Willow Creek, west of Stavely & 50.1 & -114.0 \\
\hline 68 & 7-Aug-00 & Little Bow, south of Travers & 50.1 & -112.7 \\
\hline 8037 & 23-Aug-00 & Vauxhall, at DU project & 50.1 & -112.1 \\
\hline 8041 & 24-Aug-00 & Vauxhall Canal & 50.1 & -112.1 \\
\hline 8114 & 24-Aug-00 & Hays irrigation canal & 50.1 & -111.8 \\
\hline 8213 & 23-Aug-00 & 12 Mile Coulee Creek & 50.1 & -111.7 \\
\hline 1540 & 24-Jul-00 & Echodale Park, west of Medicine Hat & 50.1 & -110.9 \\
\hline 8050 & $30-$ Aug-00 & Redcliff Coulee & 50.1 & -110.8 \\
\hline 70 & 31-Aug-00 & Mitchell Creek, northeast of Medicine Hat & 50.1 & -110.6 \\
\hline 128 & 12-Jul-00 & Chain Lakes Reservoir & 50.2 & -114.2 \\
\hline 32402 & $20-$ Aug- 00 & Oxley (Oxley Creek) & 50.2 & -113.9 \\
\hline 32400 & 24-Aug-00 & EID Canal southeast of Scandia & 50.2 & -112.0 \\
\hline 8326 & 12-Jul-00 & Mosquito Creek & 50.3 & -114.2 \\
\hline 51299 & 6-Aug-00 & Scandia, near Bow City & 50.3 & -112.1 \\
\hline 110 & 5 -Aug-00 & Lonesome Lake, north of & 50.4 & -112.3 \\
\hline 77 & 23-Jun-00 & Lake Newell, south of & 50.4 & -111.9 \\
\hline 51323 & 5-Jun-00 & Brooks, south of & 50.5 & -111.9 \\
\hline 17 & 5-Jun-00 & Johnson/Jamicsan Lake, north of Brooks & 50.6 & -111.9 \\
\hline 32396 & 5 -Jun- 00 & Onetree Reservoir & 50.6 & -111.8 \\
\hline 33 & 21-Jul-00 & Okotoks Campground & 50.7 & -113.9 \\
\hline 108 & 2001 & San Francisco Lake, near Brooks & 50.7 & -112.1 \\
\hline 116 & 6-Jun-00 & Millicent & 50.7 & -111.8 \\
\hline 32390 & 6-Jun-00 & Princess & 50.7 & -111.5 \\
\hline 7131 & 26-Sep-01 & Millarville, west of & 50.8 & -114.3 \\
\hline 32394 & 4-Aug-00 & Bow River, southwest of Bassano & 50.8 & -112.6 \\
\hline $8199 / 19655$ & 17-Jun-00 & Dinosaur Park & 50.8 & -111.5 \\
\hline 81 & 9-Aug-00 & Jenner Springs, near Jenner & 50.8 & -111.0 \\
\hline 94 & 25-Jul-00 & Priddis Creek, near Priddis & 50.9 & -114.6 \\
\hline 1573 & 25-Jul-00 & Wildrose Country Estates (Bragg Creek) & 50.9 & -114.6 \\
\hline 20 & 25-Jul-00 & Priddis Creek Golf Course & 50.9 & -114.4 \\
\hline 111 & 25-Jul-00 & Fish Creek / Whiskey Creek, near Priddis & 50.9 & -114.4 \\
\hline 21 & 25-Jul-00 & Priddis / Fish Creek & 50.9 & -114.3 \\
\hline 96 & 24-Jul-00 & Fish Creek Park, Calgary & 50.9 & -114.1 \\
\hline 1561 & 5-Jul-00 & Stobart & 50.9 & -113.2 \\
\hline 8031 & $5-$ Oct-01 & Gleichen, in or near & 50.9 & -113.1 \\
\hline 1550 & 2001 & Brooks Pheasant Hatchery (area) & 50.9 & -112.0 \\
\hline
\end{tabular}

* Records 1 to 136 represent ANHIC records; other numbers indicate BSOD records. 
Appendix 2. continued

\begin{tabular}{|c|c|c|c|c|}
\hline Record* & Date & Site Description & Latitude & Longitude \\
\hline 18965 & 2001 & Brooks, north of & 50.9 & -112.0 \\
\hline 117 & 6-Jun-00 & Wardlow & 50.9 & -111.6 \\
\hline 84 & 7-Jun-00 & Howie & 50.9 & -111.3 \\
\hline 5484 & 16-Oct-01 & Red Deer River, north of & 50.9 & -111.2 \\
\hline 51309 & 10 -Aug-00 & Red Deer River, northwest of Bindloss & 50.9 & -110.4 \\
\hline 9524 & $17-$ Sep-01 & Calgary, west of & 51.0 & -114.2 \\
\hline 97 & 13-Jul-00 & Glenmore Park, Calgary & 51.0 & -114.1 \\
\hline 100 & 18-Jul-00 & Westmill Shopping Center - Calgary & 51.0 & -114.1 \\
\hline 98 & 14-Jul-00 & Beaver Dam Flats Park, Calgary & 51.0 & -114.0 \\
\hline 99 & $10-J u l-00$ & Inglewood Bird Sanctuary - Calgary & 51.0 & -114.0 \\
\hline 25 & 2-Jun-00 & Eagle Lake & 51.0 & -113.3 \\
\hline 124 & 16-Oct-01 & Red Deer River / Douglas Creek & 51.0 & -112.0 \\
\hline 122 & 6-Jun-00 & Hutton & 51.0 & -111.8 \\
\hline 101 & 3-Aug-00 & Westchete Gravel Pits -Calgary (Bowmont Flats) & 51.1 & -114.2 \\
\hline 9481 & 26-Jul-00 & Bearspaw & 51.1 & -114.2 \\
\hline 95 & 14-Jul-00 & Edworthy Park, Calgary & 51.1 & -114.1 \\
\hline 1571 & $3-$ Aug-00 & Nosehill Park, Calgary & 51.1 & -114.1 \\
\hline $8116 / 8124$ & $20-\mathrm{Jul}-00$ & Nose Creek (Calgary) & 51.1 & -114.1 \\
\hline $\begin{array}{c}8110 / 8056 / 11092 / \\
8030 / 20382-84\end{array}$ & 11-Jul-00 & Calgary & 51.1 & -114.1 \\
\hline 8125 & 20-Jul-00 & Airport Road (Calgary) & 51.1 & -114.0 \\
\hline 51324 & 2-Jun-00 & Strathmore, area & 51.1 & -113.4 \\
\hline 1575 & 2000 & Alkali Creek, west of Bindloss & 51.1 & -110.7 \\
\hline 9562 & 26-Jul-00 & Beaupre Creek & 51.2 & -114.6 \\
\hline 104 & 26-Jul-00 & Mitford, west of Calgary & 51.2 & -114.5 \\
\hline 103 & 19-Jul-00 & Bighill Creek (Cochrane) & 51.2 & -114.4 \\
\hline 102 & 14-Jul-00 & Beddington Creek, Calgary & 51.2 & -114.1 \\
\hline 9519 & 25-May-00 & Rockyford & 51.2 & -113.1 \\
\hline 88 & 28-Jun-00 & Severn Reservoir / Creek & 51.2 & -113.0 \\
\hline $9455 / 19656$ & $11-$ Aug-00 & Acadia Valley & 51.2 & -110.3 \\
\hline 1037 & 19-Jul-00 & Bottrel - Horse Creek & 51.3 & -114.6 \\
\hline $1572 / 39031$ & 19-Jul-00 & Bottrel & 51.3 & -114.5 \\
\hline $9513 / 11091$ & 26-May-00 & Rosebud & 51.3 & -112.9 \\
\hline 8021 & 6-Sep-01 & Locality of Beyon, in or near & 51.3 & -112.8 \\
\hline 1568 & 10 -Sep-01 & Crossfield & 51.4 & -114.0 \\
\hline 5181 & 6-Sep-01 & Willow Creek area & 51.4 & -112.6 \\
\hline 89 & 20-Jun-00 & Little Fish Lake & 51.4 & -112.2 \\
\hline 51335 & 19-Jul-00 & Harold Creek (Waiparous) & 51.5 & -114.9 \\
\hline 1038 & $27-J u n-00$ & Carbon & 51.5 & -113.1 \\
\hline 32385 & 24-May-00 & Sharples & 51.5 & -113.0 \\
\hline 51327 & 24-May-00 & Hesketh, northeast of & 51.5 & -112.9 \\
\hline
\end{tabular}

* Records 1 to 136 represent ANHIC records; other numbers indicate BSOD records. 
Appendix 2. continued

\begin{tabular}{|c|c|c|c|c|}
\hline Record* & Date & Site Description & Latitude & Longitude \\
\hline 51314 & 24-May-00 & Kneehill Creek, near Drumheller & 51.5 & -112.8 \\
\hline 8192 & 31-Aug-01 & Sundre, south of - Fallen Timber Creek & 51.6 & -114.6 \\
\hline 8005 & 6-Sep-01 & Morrin & 51.7 & -112.8 \\
\hline $8018-20$ & 6-Sep-01 & Drumheller area & 51.7 & -112.7 \\
\hline 136 & 14-Jul-00 & Dowling Lake, southwest corner & 51.7 & -112.1 \\
\hline 135 & 4-Jul-00 & Dowling Lake, southeast corner & 51.7 & -112.0 \\
\hline 19657 & 29-May-00 & Trochu, at Red Deer River & 51.8 & -113.0 \\
\hline 5921 & 3-Aug-00 & Big Valley area & 51.9 & -112.7 \\
\hline 8034 & 20-Aug-01 & Crammond, in or near & 52.0 & -114.7 \\
\hline 8193 & $20-$ Aug-01 & Caroline, 6 mile $\mathrm{S}$ of & 52.0 & -114.6 \\
\hline 105 & $5-$ Aug-00 & Unnamed creek, near Ricinus & 52.1 & -115.0 \\
\hline 120 & 15 -Aug-00 & Beaver Creek, near Caroline & 52.1 & -114.7 \\
\hline 51333 & 20-Aug-01 & Raven River, near Caroline & 52.1 & -114.7 \\
\hline 51332 & 31-Aug-01 & Clearwater River, near Dovercourt & 52.2 & -114.9 \\
\hline 90 & 2-Aug-00 & Slacks Slough, south of Red Deer & 52.2 & -113.8 \\
\hline 5226 & 3-Aug-00 & Stettler, area near & 52.2 & -112.7 \\
\hline 51315 & 14-Jul-01 & Eyehill Creek, near Bodo & 52.2 & -110.1 \\
\hline 51326 & 2000 & Gaetz Lakes, Red Deer & 52.3 & -113.8 \\
\hline 125 & 16-Aug-00 & Tail Creek, near Nevis & 52.3 & -113.1 \\
\hline 1577 & 14-Aug-00 & Chambers Creek Camp Ground & 52.4 & -115.3 \\
\hline 9546 & $17-$ Oct-00 & Chambers Lake / Buster Creek & 52.4 & -115.2 \\
\hline 19 & 4-Aug-00 & Crimson Lake Provincial Park & 52.4 & -115.0 \\
\hline 18 & 15-Aug-00 & Rocky Mountain House area & 52.4 & -114.9 \\
\hline 51316 & 14-Jul-01 & Hayter, north of & 52.4 & -110.1 \\
\hline 5487 & 5-Aug-00 & $\begin{array}{l}\text { West Lobstick Creek, northeast of Rocky } \\
\text { Mountain House }\end{array}$ & 52.5 & -114.8 \\
\hline $9497 / 9499$ & 2-Aug-00 & Aspen Beach Provincial Park & 52.5 & -114.0 \\
\hline 9458 & 3 -Aug-00 & Rochon Sands Provincial Park & 52.5 & -112.9 \\
\hline 9462 & 15 -Aug-00 & Buffalo Lake & 52.5 & -112.9 \\
\hline 19658 & 15-Jul-01 & Black Creek, southeast of Ribstone & 52.5 & -110.4 \\
\hline 9496 & 4-Aug-00 & Grace Creek, northwest of Rocky Mountain House & 52.6 & -115.3 \\
\hline 51337 & 2-Aug-00 & J.J. Coullet Natural Area, near Morningside & 52.6 & -113.6 \\
\hline 608 & 18-Sep-01 & Buffalo Lake, north of & 52.6 & -112.9 \\
\hline 91 & 17-Aug-00 & Killarney Lake & 52.6 & -110.1 \\
\hline 9516 & 14-Jul-01 & Dillberry Lake & 52.6 & -110.0 \\
\hline 92 & 16-Aug-00 & Hardisty & 52.7 & -111.3 \\
\hline 52782 & 30-Jul-01 & Battle River, near Wainwright & 52.9 & -111.0 \\
\hline 132 & 7-Sep-00 & Cawes Lake & 53.4 & -113.4 \\
\hline $9445 / 9448 / 9452$ & 2000 & Vermillion Provincial Park & 53.4 & -111.0 \\
\hline 134 & 2000 & Edmonton, $\mathrm{U}$ of $\mathrm{A}$ farm & 53.5 & -113.5 \\
\hline 133 & 2000 & $\begin{array}{l}\text { Walter Lake / Blackfoot Recreation area, near } \\
\text { Uncas }\end{array}$ & 53.5 & -112.9 \\
\hline
\end{tabular}

* Records 1 to 136 represent ANHIC records; other numbers indicate BSOD records. 
Appendix 2. continued

\begin{tabular}{|c|c|l|c|c|}
\hline Record* & Date & Site Description & Latitude & Longitude \\
\hline 106 & 8-27 Aug 01 & Heatherdown, near Stony Plain & 53.6 & -114.1 \\
\hline 51334 & 8-24 Aug 01 & Kilini Creek; Glory Hills & 53.6 & -114.1 \\
\hline 8032 & 18 -Sep-00 & Edmonton & 53.6 & -113.5 \\
\hline 1581 & 2001 & Edmonton & 53.6 & -113.3 \\
\hline 1580 & 2001 & Ardrossan, west of & 53.6 & -113.0 \\
\hline 1576 & 8 -27 Aug 01 & Chip Lake area & 53.7 & -115.3 \\
\hline 130 & 8-27 Aug 01 & Thunder Lake Provincial Park & 54.1 & -114.7 \\
\hline 51328 & 23-Aug-01 & Long Lake Provincial Park & 54.4 & -112.8 \\
\hline 8184 & 16-Aug-01 & Little Smoky, south of & 54.6 & -117.1 \\
\hline 8366 & 24-Aug-01 & Cross Lake Provincial Park & 54.7 & -113.8 \\
\hline 959 & 9-Sep-00 & Muskoseepi Reservoir & 55.1 & -118.9 \\
\hline 8183 & 28-Sep-00 & Sturgeon Creek & 55.2 & -117.3 \\
\hline 51330 & 16-Aug-01 & Lesser Slave Lake Provincial Park & 55.3 & -114.7 \\
\hline 9498 & 23-Aug-01 & Highlevel, east of & 58.5 & -116.9 \\
\hline 39041 & 19-Aug-00 & $\begin{array}{l}\text { Bocquene Lake and wetlands, east of Wood } \\
\text { Buffalo National Park }\end{array}$ & 59.5 & -111.0 \\
\hline
\end{tabular}

* Records 1 to 136 represent ANHIC records; other numbers indicate BSOD records.

Hard copies of the data sheets and information collected during the 2000 and 2001 inventory are held at the O.S. Longman Building, Edmonton, Alberta. 
Appendix 3. Northern leopard frog sites not investigated during the 2000-2001 inventory because access was denied, poor site description or coordinates, or other reason.

\begin{tabular}{|c|c|c|c|}
\hline Record* & Site Description & Latitude & Longitude \\
\hline 30 & Milk River & 49.1 & -112.0 \\
\hline 61 & Bow Island, along Bow River & 49.9 & -111.7 \\
\hline 8024 & Tilley, in or near & 50.4 & -111.6 \\
\hline 51300 & Tilly & 50.4 & -111.6 \\
\hline 7489 & CFB Suffield & 50.4 & -110.5 \\
\hline 7493 & CFB Suffield & 50.4 & -110.4 \\
\hline 7495 & CFB Suffield & 50.4 & -110.4 \\
\hline 115 & Bull Springs Coulee, at South Sask. River & 50.5 & -110.5 \\
\hline 7490 & CFB Suffield & 50.5 & -110.4 \\
\hline 7494 & CFB Suffield & 50.5 & -110.4 \\
\hline 51301 & Cassels & 50.6 & -112.0 \\
\hline 112 & Dishpan Lake - Ross Depression & 50.6 & -110.6 \\
\hline 7491 & CFB Suffield & 50.6 & -110.4 \\
\hline 7492 & CFB Suffield & 50.6 & -110.4 \\
\hline 74 & Rock Lake & 50.7 & -112.0 \\
\hline 5486 & Okotoks, northeast of & 50.8 & -113.9 \\
\hline 52 & Alkali Creek, northeast of Buffalo & 50.8 & -110.4 \\
\hline 121 & Cavandish & 50.9 & -110.5 \\
\hline 51303 & Red Deer at Hutton Springs & 51.0 & -112.0 \\
\hline $51325 / 8054$ & Hussar, east of & 51.1 & -112.7 \\
\hline 51331 & Clearwater River & 52.1 & -114.9 \\
\hline 129 & Gooseberry Lake & 52.1 & -110.8 \\
\hline 9456 & Hinton & 53.4 & -117.8 \\
\hline 52482 & Devon, northwest of & 53.4 & -113.8 \\
\hline 51287 & Rossington & 54.2 & -114.1 \\
\hline 9475 & Garner Lake Provincial Park & 54.2 & -111.8 \\
\hline 8004 & Lake Athabasca & 59.0 & -111.5 \\
\hline 126 & Fitzgerald & 59.8 & -111.6 \\
\hline
\end{tabular}

* Records 1 to 136 represent ANHIC records; other numbers indicate BSOD records. 
Appendix 4. List of all sites occupied by leopard frogs during the 2000-2001 inventory grouped by drainage; the number of sites associated with each drainage, tributary or waterbody are indicated in brackets.

\begin{tabular}{|c|c|c|c|}
\hline Drainage & First Tributary (Second Tributary) & Waterbody & $\begin{array}{l}\text { Number } \\
\text { of Sites }\end{array}$ \\
\hline \multirow[t]{8}{*}{ Red Deer River (7) } & - & - & 1 \\
\hline & Onetree Creek & - & 1 \\
\hline & Blood Indian Creek & - & 1 \\
\hline & Empress Creek & - & 1 \\
\hline & Kennedy Coulee (tributary) & - & 1 \\
\hline & Spring Creek & - & 1 \\
\hline & Serviceberry Creek (Rosebud River) & - & 1 \\
\hline & - & Stafford Lake (1) & 1 \\
\hline \multirow[t]{3}{*}{ Oldman River (4) } & - & - & 1 \\
\hline & Pine Creek (Willow Creek) & - & 1 \\
\hline & Willow Creek & - & 2 \\
\hline \multirow[t]{5}{*}{ South Saskatchewan River (12) } & - & - & 7 \\
\hline & Kin Coulee (tributary) & - & 1 \\
\hline & Old Channel Lake & - & 1 \\
\hline & Bullshead Creek & - & 1 \\
\hline & Persons Creek & - & 2 \\
\hline \multirow[t]{5}{*}{ Bow River (10) } & - & - & 4 \\
\hline & Twelve Mile Coulee (tributary) & - & 1 \\
\hline & Lonesome Lake/Drainage K & - & 2 \\
\hline & Minipoka Drain & - & 1 \\
\hline & Little Bow River & - & 1 \\
\hline \multirow[t]{10}{*}{ Milk River (15) } & - & - & 3 \\
\hline & Kennedy Creek & - & 1 \\
\hline & Police Creek & - & 1 \\
\hline & Red Creek & - & 1 \\
\hline & Thelma Creek (Lodge Creek) & - & 1 \\
\hline & Sexton Creek (Lodge Creek) & - & 1 \\
\hline & Lodge Creek (Lodge Creek) & - & 3 \\
\hline & Battle Creek & - & 2 \\
\hline & Bare Creek (Lodge Creek) & - & 1 \\
\hline & Breed Creek & - & 1 \\
\hline \multirow[t]{2}{*}{ Slave River (2) } & (via Dog River) (1) & Leland Lake & 1 \\
\hline & (via Lake Athabasica) (1) & Wylie Lake & 1 \\
\hline- & - & Prince's Spring (1) & 1 \\
\hline (tributary of Many Island Lake) (1) & McAlpine Creek & - & 1 \\
\hline \multirow[t]{2}{*}{ (tributary of Pakowki Lake) (2) } & Manyberries Creek & - & 1 \\
\hline & Ketchum Creek & - & 1 \\
\hline & & TOTAL & 54 \\
\hline
\end{tabular}

Numbers within brackets indicate total number of sites associated with a waterbody, tributary or major drainage. 
Appendix 5. Ten major leopard frog populations identified during the 1990 inventory (Wershler 1991) and their current status with respect to the presence of frogs at one or more sites as of 2001.

\begin{tabular}{|c|c|c|}
\hline Major Populations (1990) & $\begin{array}{l}\text { Presence of frogs at one or more } \\
\text { sites }(2000-2001)\end{array}$ & $\begin{array}{l}\text { Record \# of each site where one or } \\
\text { more leopard frogs were detected** } \\
\text { (significant sites in bold) }\end{array}$ \\
\hline $\begin{array}{l}\text { Cypress Hills (B) } \\
\text { - } \quad \begin{array}{l}\text { reservoirs, creeks and ponds in } \\
\text { the Cypress Hills }\end{array}\end{array}$ & Present (B) & $\begin{array}{l}\mathbf{5 6}, \mathbf{5 7}, 8026,8214, \mathbf{8 2 3 3} / \mathbf{5 4 2 5 5} \\
\mathbf{5 1 2 8 1}\end{array}$ \\
\hline Lost River-Canal Creek (B) & $\begin{array}{l}\text { No observations } \\
\text { (location dry) }\end{array}$ & 45,8201 \\
\hline Jenner Springs (B) & No observations & 81 \\
\hline Prince's Spring (B) & Present (B) & 83 \\
\hline $\begin{array}{l}\text { Lower Red Deer River }(\mathrm{B}) \\
-\quad \text { associated coulee streams and } \\
\text { tributaries (downstream of } \\
\text { Drumheller) }\end{array}$ & Present (B) & $85,86,87,93,118$ \\
\hline $\begin{array}{l}\text { Milk River } \\
\text { - } \quad \text { associated coulee streams in } \\
\text { vicinity of Writing on Stone } \\
\text { Provincial Park }\end{array}$ & Present (B) & 36 \\
\hline $\begin{array}{l}\text { Lower Milk River } \\
-\quad \begin{array}{l}\text { associated coulee streams and } \\
\text { tributaries in vicinity }\end{array} \\
\end{array}$ & Present (B) & $32,38,39,47,107$ \\
\hline $\begin{array}{l}\text { Grand Forks } \\
-\quad \text { near confluence of Oldman } \\
\text { River and Bow River; lower } \\
\text { Bow River }\end{array}$ & Present (B) & $66,131,32403$ \\
\hline Red Deer River - Finnegan (B)* & Present & 78 \\
\hline $\begin{array}{l}\text { Blood Indian Creek; Jenner-North } \\
(\mathrm{B})^{*}\end{array}$ & Present & 86 \\
\hline
\end{tabular}

* Unconfirmed major population in 1990.

** Records 1 to 136 are ANHIC records; other numbers indicate BSOD records; records in bold indicate sites with 10 or more adult or subadult frogs combined in 2000-2001.

(B) = Evidence of breeding (i.e. young-of-the-year observed). 
Appendix 6. Sites occupied by leopard frogs in 1990 (Wershler 1991) compared with results from the 2000-2001 at the same sites.

\begin{tabular}{|c|c|c|c|}
\hline $\begin{array}{l}\text { Site } \\
\text { No.* }\end{array}$ & Sites occupied by leopard frogs in 1990 & $\begin{array}{l}\text { Leopard frog observed? } \\
(2000-2001)\end{array}$ & Record** \\
\hline 1 & Canal Creek (B) & No (site dry) & 45 \\
\hline 2 & Prince's Spring (B) & Yes (B) & $(83)$ \\
\hline 3 & Cypress Hills - Sexton Creek (B) & Yes (B) & (56) \\
\hline 4 & Cypress Hills - Reeser Lake (Battle Creek) & Yes (B) & $(57)$ \\
\hline 5 & Jenner Springs $(\mathrm{B})$ & No & 81 \\
\hline 6 & Old Channel Lake - CFB Suffield (B) & Yes (B) & $(72)$ \\
\hline 7 & Empress Creek (B) & Yes (B) & $(87)$ \\
\hline 8 & Kennedy's Coulee (B) & Yes (B) & $(85)$ \\
\hline 9 & Bow River south of Gleichen (B) & Yes (B) & $(82)$ \\
\hline 10 & Little Bow River - south of the Travers Reservoir (B) & No & 68 \\
\hline 11 & Little Bow River, north of Coaldale (B) & No & 65 \\
\hline 12 & Bow River, east of Hays & Yes (B) & $(66)$ \\
\hline 13 & Lodge Creek & Yes (B) & $\begin{array}{l}9,49,(8026) \\
(\mathbf{8 2 3 4})\end{array}$ \\
\hline 14 & St. Mary River, oxbow of & No (site dry) & 54 \\
\hline 15 & $\begin{array}{l}\text { Police Creek, Milk River; Writing on Stone Provincial } \\
\text { Park }\end{array}$ & Yes (B) & (36) \\
\hline 16 & Slack Slough & No & 90 \\
\hline 17 & Milk River canyon and tributaries & Yes (B) & $\begin{array}{l}1,27,29,(38), \\
(39),(47)\end{array}$ \\
\hline 18 & Finnegan & Yes & (78) \\
\hline 19 & Beaver Creek (Porcupine Hills) & No & 59 \\
\hline 20 & Beaupre Creek & No & 9562 \\
\hline 21 & Horse Creek, west of Cochrane & No & 1037 \\
\hline 22 & Blood Indian Creek & Yes & $(86)$ \\
\hline 23 & Manyberries Creek and area & Yes & $55,(39042)$ \\
\hline 24 & City of Medicine Hat & Yes (B) & $\begin{array}{l}(63),(64) \\
(5137),(8027)\end{array}$ \\
\hline
\end{tabular}

* Site No. in italics indicate sites that are the result of a poster campaign by Alberta Fish and Wildlife and World Wildlife Fund Canada that solicited information on the leopard frog from the public. The listed sites were believed to be accurate (see Wershler 1991).

** Records 1 to 136 are ANHIC records; other numbers indicate BSOD records. ANHIC or BSOD records in brackets indicate sites with confirmed leopard frogs during 2000-2001 inventory; records in bold indicate sites with 10 or more adult and subadult frogs combined in 2000-2001.

(B) = Evidence of breeding (i.e. young-of-the-year observed). 


\section{List of Titles in This Series}

(as of March 2002)

No. 1 Alberta species at risk program and projects 2000-2001, by Alberta Sustainable Resource Development, Fish and Wildlife Division. (2001)

No. 2 Survey of the peregrine falcon (Falco peregrinus anatum) in Alberta, by R. Corrigan. (2001)

No. 3 Distribution and relative abundance of the shortjaw cisco (Coregonus zenithicus) in Alberta, by M. Steinhilber and L. Rhude. (2001)

No. 4 Survey of the bats of central and northwestern Alberta, by M.J. Vonhof and D. Hobson. (2001)

No. 52000 survey of the Trumpeter Swan (Cygnus buccinator) in Alberta, by M.L. James and A. James. (2001)

No. 6 2000/2001 Brassy Minnow inventory at Musreau Lake and outlet, by T. Ripley. (2001)

No. 7 Colonial nesting waterbird survey in the Northwest Boreal Region - 2000, by M. Hanneman and M. Heckbert. (2001)

No. 8 Burrowing owl trend block survey and monitoring - Brooks and Hanna areas, by D. Scobie and R. Russell. (2000)

No. 9 Survey of the Lake Sturgeon (Acipenser fulvescens) fishery on the South Saskatchewan River, Alberta (June-September, 2000), by L.A. Winkel. (2000)

No. 10 An evaluation of grizzly bear-human conflict in the Northwest Boreal Region of Alberta (19912000) and potential mitigation, by T. Augustyn. (2001)

No. 11 Harlequin duck monitoring in the Northern East Slopes of Alberta: 1998-2000 preliminary results, by J. Kneteman and A. Hubbs. (2000)

No. 12 Distribution of selected small mammals in Alberta, by L. Engley and M. Norton. (2001)

No. 13 Northern leopard frog reintroduction. Raven River - Year 2 (2000), by K. Kendell. (2001)

No. 14 Cumulative effects of watershed disturbances on fish communities in the Kakwa and Simonette watersheds. The Northern Watershed Project. Study 3 Progress report, by T. Thera and A. Wildeman. (2001)

No. 15 Harlequin duck research in Kananaskis Country in 2000, by C.M. Smith. (2001)

No. 16 Proposed monitoring plan for harlequin ducks in the Bow Region of Alberta, by C.M. Smith. (2001)

No. 17 Distribution and relative abundance of small mammals of the western plains of Alberta as determined from great horned owl pellets, by D. Schowalter. (2001)

No. 18 Western blue flag (Iris missouriensis) in Alberta: a census of naturally occurring populations for 2000 , by R. Ernst. (2000)

No. 19 Assessing chick survival of sage grouse in Canada, by C.L. Aldridge. (2000)

No. 20 Harlequin duck surveys of the Oldman River Basin in 2000, by D. Paton. (2000) 
No. 21 Proposed protocols for inventories of rare plants of the Grassland Natural Region, by C. Wallis. (2001)

No. 22 Utilization of airphoto interpretation to locate prairie rattlesnake (Crotalus viridis viridis) hibernacula in the South Saskatchewan River valley, by J. Nicholson and S. Rose. (2001)

No. 23 2000/2001 Progress report on caribou research in west central Alberta, by T. Szkorupa. (2001)

No. 24 Census of swift fox (Vulpes velox) in Canada and Northern Montana: 2000-2001, by A. Moehrenschlager and C. Moehrenschlager. (2001)

No. 25 Population estimate and habitat associations of the long-billed curlew in Alberta, by E.J. Saunders. (2001)

No. 26 Aerial reconnaissance for piping plover habitat in east-central Alberta, May 2001, by D.R.C. Prescott. (2001)

No. 27 The 2001 international piping plover census in Alberta, by D.R.C. Prescott. (2001)

No. 28 Prairie rattlesnake (Crotalus viridis viridis) monitoring in Alberta - preliminary investigations (2000), by S.L. Rose. (2001)

No. 29 A survey of short-horned lizard (Phrynosoma hernandesi hernandesi) populations in Alberta, by J. James. (2001)

No. 30 Red-sided garter snake (Thamnophis sirtalis parietalis) education and relocation project - final report, by L. Takats. (2002)

No. 31 Alberta furbearer harvest data analysis, by K.G. Poole and G. Mowat. (2001)

No. 32 Measuring wolverine distribution and abundance in Alberta, by G. Mowat. (2001)

No. 33 Woodland caribou (Rangifer tarandus caribou) habitat classification in northeastern Alberta using remote sensing, by G.A. Sanchez-Azofeifa and R. Bechtel. (2001)

No. 34 Peregrine falcon surveys and monitoring in the Parkland Region of Alberta, 2001, by R. Corrigan. (2002)

No. 35 Protocol for monitoring long-toed salamander (Ambystoma macrodactylum) populations in Alberta, by T. Pretzlaw, M. Huynh, L. Takats and L. Wilkinson. (2002)

No. 36 Long-toed salamander (Ambystoma macrodactylum) monitoring study in Alberta: summary report 1998-2001, by M. Huynh, L. Takats and L. Wilkinson. (2002)

No. 37 Mountain plover habitat and population surveys in Alberta, 2001, by C. Wershler and C. Wallis. (2002)

No. 38 A census and recommendations for management for western blue flag (Iris missouriensis) in Alberta, by R. Ernst. (2002)

No. 39 Columbian mountain amphibian surveys, 2001, by D. Paton. (2002)

No. 40 Management and recovery strategies for the Lethbridge population of the prairie rattlesnake, by R. Ernst. (2002) 
No. 41 Western (Aechmophorus occidentalis) and eared (Podiceps nigricollis) grebes of central Alberta: inventory, survey techniques and management concerns, by S. Hanus, H. Wollis and L. Wilkinson. (2002)

No. 42 Northern leopard frog reintroduction - year 3 (2001), by K. Kendell. (2002)

No. 43 Survey protocol for the northern leopard frog, by K. Kendell. (2002)

No. 44 Alberta inventory for the northern leopard frog (2000-2001), by K. Kendell. (2002) 
National Library of Canada

Bibliotheque nationale du Canada

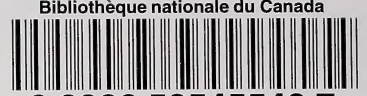

33286525455487 